\title{
COMMENT
}

\section{CRIMINAL OFFENDERS IN THE JUVENILE COURT: MORE BRICKBATS AND ANOTHER PROPOSAL}

Morris A. Kent, Jr. was arrested for housebreaking, robbery and rape on September 5, 1961. Because he was only sixteen years old the juvenile court obtained jurisdiction of his case. Thus began the tortured journey of one of the most important and instructive cases in the history of juvenile court litigation in this country. It is presently in its fifth year, having been remanded to the United States district court by a decision of the Supreme Court handed down on March 21, 1966.1 After beginning in the Juvenile Court of the District of Columbia, passing through five courts supplying the subject matter for five opinions culminating in the decision by the Supreme Court, Kent v. United States has come to represent a catalogue of the maladies which afflict the juvenile court system.

Kent was under the jurisdiction of the juvenile court as a probationer for the two years preceding his arrest. Because of this situation, Kent's mother feared that the juvenile court might decide to relinquish its jurisdiction so that Kent could be prosecuted as an adult before the district court. Such a procedure is provided by a District of Columbia statute which permits waiver of jurisdiction "after full investigation" in the cases of juveniles over sixteen accused of committing acts considered felonies, or juveniles accused of committing acts punishable by death or life imprisonment under ordinary criminal procedure. ${ }^{2}$ Except for the requirement of "full investigation," no standard is set forth in the statute to guide the juvenile court judge in the exercise of his discretion.

Because of her fear of waiver, Kent's mother obtained an interview with the director of social work of the juvenile court to persuade against relinquishment of jurisdiction. Kent's counsel ${ }^{3}$ submitted a memorandum arguing against waiver and a psychiatrist's report concerning his client's mental condition. With this material and the minor's records before him, including his social records compiled by the social work staff of the juvenile court, the juvenile court judge decided to waive jurisdiction on September 12, 1961. The importance of this decision may be appreciated only after one considers that it could spell the difference between a maximum imprisonment of five years in a juvenile institution and the possibility of the death penalty or many years of incarceration in an adult prison and daily

1 Kent v. United States, 86 Sup. Ct. 1045 (1966).

2 D.C. Code ANN. \$11-1553 (Supp. V, 1966).

3 Kent had the uncommon advantage of being represented before the juvenile court. See note 83 infra. 
contact with hardened criminals. ${ }^{4}$ In conceptual terms, the decision to relinquish jurisdiction moved the juvenile from the rehabilitative philosophy of the juvenile court to the regular criminal processes, where the notions of retribution and deterrence play an important role.

In spite of the obvious importance of the decision, the juvenile court judge did not feel that a hearing was required. Thus Kent's lawyer was never given an opportunity to argue his case before the court, the minor had no opportunity to testify in support of his cause and the conclusions of the social workers, set out in the social record upon which the judge may have relied, were never subjected to the probing analysis of crossexamination. From the face of the statute, it appears that the legislature concurred in the court's opinion that a hearing in waiver cases is unnecessary, for it neglected explicitly to require one. ${ }^{\overline{5}}$

The problems encountered by Morris Kent did not stop with the failure to afford him a hearing. The court, in the exercise of its discretion, refused to permit his social records to be examined either by his lawyer or by the psychiatrists retained by him. Of course, the lack of a hearing resulted in the absence of a transcript of proceedings, so there was no way to determine what factors played a role in the decision. Nor did the juvenile court judge feel constrained to tell the world the basis of his decision to send Morris Kent to the criminal court. Intoning the words of the waiver statute, the order of the juvenile court stated cryptically that "after full investigation" jurisdiction was relinquished. Kent was held for trial under the regular procedures of the district court, and two weeks later an indictment for eight offenses was returned against him. At this stage in the litigation-with no record, no opinion and no indication of the standards applied to remove him from the juvenile court-Kent entered an appellate maze seeking reversal of the juvenile court.

Kent pursued two courses of attack; he filed a writ of habeas corpus in the district court to challenge its jurisdiction, and he appealed the waiver order to the District of Columbia Municipal Court of Appeals (now the

4 See Kent v. United States, 86 Sup. Ct. 1049, 1053 (1966). The juvenile court's jurisdiction over a minor ceases when he becomes twenty-one. D.C. CODE ANN. $\$ 11-1551$ (Supp. V, 1966). When Kent was indicted before the district court he was charged with rape, which carries a possible death penalty, D.C. CoDE ANN. \$22-2801 (1961), house breaking carrying a fifteen year maximum penalty, D.C. CoDE ANN. $\$ 22-1801$ (1961), and robbery, carrying a fifteen year maximum penalty. D.C. CoDE ANN. \$22-2901 (1961).

Upon conviction in the district court Kent was sentenced to a term of from thirty to ninety years.

\section{The statute reads:}

When a child 16 years of age or over is charged with an offense which if committed by a person 18 years of age or over is a felony, or when a child under 18 years of age is charged with an offense which if committed by a person 18 years of age or over is punishable by death or life imprisonment, a judge may, after full investigation, waive jurisdiction and order the child held for trial under the regular procedure of the court which would have jurisdiction of the offense if committed by a person 18 years of age or over ....

D.C. Code ANn. \&11-1553 (Supp. V, 1966). 
District of Columbia Court of Appeals) under the general appeal statute. ${ }^{6}$ On September 19, 1961, the writ of habeas corpus was dismissed without opinion, and on April 13, 1962, the Municipal Court of Appeals affirmed the juvenile court in a short opinion, holding that the requirement of full investigation had been met by the juvenile court and that the lack of standards in the waiver statute did not violate "fundamental fairness" concepts of due process. ${ }^{7}$ Both these judgments were appealed to the Court of Appeals for the District of Columbia, which held that habeas corpus did not lie to attack the jurisdiction of the district court and that waiver was not a final order and, therefore, could not be appealed to the Municipal Court of Appeals. ${ }^{8}$ The basis of the court's decision was a fear that attacks on waiver at that stage would cause delay and that the record was "woefully inadequate." 9 A motion to dismiss the indictment before the district court was offered as the solution, and such a motion was pending before that court. This last pre-trial appeal was denied on January 22, 1963.

After the denial of the motion to dismiss the indictment, Kent proceeded to trial and was found guilty by a jury of three counts of housebreaking and three counts of robbery and not guilty of rape by reason of insanity.

In October, 1964, the court of appeals finally reached the merits of the $K e n t$ case and affirmed both the waiver and the conviction. ${ }^{10}$ Responding to the minor's allegation that the relinquishment of jurisdiction had violated the philosophy of the juvenile court system, commonly referred to as parens patriae, the court after three years finally came to grips with the nature of the process of waiver; the court stated:

We cannot say, from an examination before us, that the Juvenile Court's waiver in this case was wholly at odds with the parens patriae philosophy of the statutory scheme under which that Court functions. For the system to operate as intended, the Court must have a wide discretion in both the formulation and the application of a waiver policy. The reviewing function of the District Court . . must necessarily reside within narrow limits and depend, for its affirmative exercise, upon demonstrable existence of arbitrariness or capriciousness. ${ }^{11}$

The court found specifically that the various reports and the two year experience with Kent as a probationer satisfied the full investigation re-

${ }^{6}$ See In the Matter of Kent, 179 A.2d 727 (D.C. Munic. Ct. App. 1962).

7 Ibid.

8 Kent v. Reid, 316 F.2d 331 (D.C. Cir. 1963).

9 Id. at 334,335 . It should be noted that the state of the record had not substantially improved when almost two years later the case finally reached the Third Circuit again for decision on the merits.

10 Kent v. United States, 343 F.2d 247 (D.C. Cir. 1964).

11 Id. at 252. 
quirement and the failure to permit counsel to examine the social records did not constitute deprivation of effective assistance. Tucked away in a footnote was the suggestion that an opinion by the juvenile court stating the basis for the waiver would be helpful, although not required. ${ }^{12}$ Hardly a mention was made of the absence of a hearing.

Few, if any, juvenile court cases have been heard by the United States Supreme Court; however, after the decision of the D.C. Circuit the high court granted Kent's petition for certiorari and reversed the court of appeals. ${ }^{13}$ The Court recognized that the juvenile court has considerable latitude within which to determine whether it should retain jurisdiction, but held that this latitude did not "confer upon the Jurvenile Court a license for arbitrary procedure," nor would it be permitted to dispense with "procedural regularity sufficient in the particular circumstances to satisfy the basic requirements of due process and fairness . . . ."14 The Supreme Court, however, declined to discuss the constitutional issues involved in the lax procedures of the juvenile court and confined itself to an interpretation of the statute in light of decisions of the D.C. Circuit which were announced after Kent..$^{15}$ The Court held that "the statute read in the context of constitutional principles relating to due process and the assistance of counsel" requires, as a condition of waiver, that the juvenile court afford the minor a hearing, permit his counsel access to the juvenile court records and deliver an opinion stating the reasons why a waiver was effected.16 Morris Kent is twenty-one now, too old to be brought under the jurisdiction of the juvenile court. It took five years and five courts to decide that he was entitled to reasonable procedural protections during a litigation in the juvenile court which was of enormous consequence to him-protections which would have been afforded adults as a matter of course. ${ }^{17}$

But how much did the Supreme Court really settle in Kent? The case could not be remanded to the juvenile court for a redetermination of the waiver because Kent was twenty-one, ${ }^{18}$ but a redetermination under the new procedural requirements is necessary because it has been held that if the waiver was unjustified, a subsequent criminal conviction must be vacated and the indictment dismissed. ${ }^{19}$ Consequently, the Supreme Court

12 No opinion accompanied the decision. Although none is required by the statute, a useful purpose might be served in some cases at least by a discussion of the reasons motivating the determination. Unaided by such a discussion, our task remains the one of weighing the decision in the light of what the record discloses.

$I d$. at 253 n.6. As there was no hearing, it is difficult to understand what the record could disclose.

13 Kent v. United States, 86 Sup. Ct. 1045 (1966).

14 Id. at 1053 .

15 Id. at 1054-55.

16 Id. at 1055 .

17 Of course, Kent received all the procedural protections afforded an adult during the litigation in the criminal court.

18 See note 4 supra.

19 See Black v. United States, No. 19038, D.C. Cir., Dec. 8, 1965, discussed in Kent v. United States, 86 Sup. Ct. 1045, 1059 (1966). 
felt that it had no alternative but to reverse the court of appeals and the district court and remand the case to the district court for a de novo hearing to determine whether the waiver, when made, was "inappropriate." If it should so find, the district court was directed to vacate the conviction. ${ }^{20}$ This solution raises serious problems, because the Court did not discuss the standards under which waiver would be permitted except to recognize the wide latitude of the juvenile court in developing policy in this area. With only the "full investigation" standard required by statute, the district court is forced to make a basic policy judgment when the juvenile court, the supposed expert, has no announced policy. Under this state of affairs it is difficult to understand how the district court will be able to make a knowledgeable judgment as to whether the waiver was "inappropriate."

The Supreme Court's opinion, therefore, undoubtedly represents an important advance in affording procedural protections to juvenile offenders in the District of Columbia and may be a warning to other similarly lax jurisdictions ; ${ }^{21}$ but it does not reach one important aspect of the problemthe lodging of almost unbridled discretion in the juvenile courts which permits them to make important decisions concerning criminal offenders under unannounced criteria. Manifestly, the law of waiver, the basis of concern in Kent, demonstrates this problem. It is set forth in a statute virtually void of criteria, and a series of similarly unilluminating opinions. ${ }^{22}$ Must a child be found incorrigible before waiver is permitted, or is the commission of one serious offense sufficient? Is overcrowding in juvenile court facilities a relevant or even permissible consideration? To what extent should the safety of the public be considered as outweighing the needs of the delinquent? What is the role of deterrence in a decision to waive? Indeed, what is the purpose behind permitting the juvenile court to relinquish jurisdiction? ${ }^{23}$ None of these questions is answered by the Supreme Court's opinion; yet the Court felt that a remand to an inexpert court was sufficient to protect the minor against inappropriate waiver when the expert court had given little indication that it knew what the appropriate waiver standards were.

\section{General Consmerations}

Two major themes underly juvenile court philosophy: 1) an adjudication to determine whether a minor is a juvenile delinquent because of the

20 Kent v. United States, supra note 19, at 1059.

21 The Supreme Court has granted a petition for certiorari in a second juvenile court case. Miller v. Rhay, No. 38216, Wash. Sup. Ct., June 16, 1965, cert. granted, 34 U.S.L. Week 3341 (U.S. March 4, 1966). Because this case arose from state court litigation, it may result in a holding concerning constitutional rights in the juvenile court.

22 See, e.g., United States v. Green, 308 F.2d 303 (D.C. Cir. 1962) ; Wilhite v. United States, 281 F.2d 642 (D.C. Cir. 1960); Briggs v. United States, 226 F.2d 350 (D.C. Cir. 1955); United States v. Caviness, 239 F. Supp. 545 (D.D.C. 1965). 23 For a fuller discussion of the problems encountered in the area of waiver of jurisdiction, see pp. 1206-12 infra. 
alleged commission of criminal acts is not a criminal action, ${ }^{24}$ and 2) the purpose of juvenile court proceedings is the treatment and rehabilitation of the minor rather than the punishment of a criminal offender. ${ }^{25}$ The latter is generally referred to as the parens patriae philosophy of the court. An important corollary is the notion that an adjudication finding the minor to be a juvenile delinquent should not carry the stigma generally associated with conviction of crime ${ }^{26}$ and will not result in any of its disabilities. ${ }^{27}$ From these underpinnings, novel lines of reasoning flow.

Characterization of juvenile court proceedings as non-criminal and the philosophy of treatment rather than punishment have caused great inroads to be made into procedural protections normally afforded criminal offenders. By calling juvenile court proceedings non-criminal, it is felt that constitutional safeguards surrounding criminal proceedings may be ignored.28 Thus, the checks on pre-trial police practices, the right of confrontation, the right to counsel, the protection against double jeopardy and other constitutional protections provided adult offenders are absent. The parens patriae or treatment philosophy has led to informal procedures of fact-finding and sentencing because it is asserted that the basis of the philosophy requires a hearing conceived as "a search for the truth" rather than a normal criminal trial with its "overly legalistic" or "technical" procedures and rules of evidence. The admission of hearsay testimony and written reports of social workers is the rule, not the exception. The hoped for effect of these informal procedures is that in a non-legal atmosphere the juvenile will be put at ease, and the absence of technical objections by counsel will expedite the fact-finding process. ${ }^{29}$ The hearing is considered part of the therapy. On the other hand, it is asserted that a normal criminal trial will be a traumatic experience for the juvenile, fixing in his own mind the stigma of criminality. ${ }^{30}$ Incarceration is considered a last resort only

24 See, e.g., Pee v. United States, 274 F.2d 556, 559-60 (D.C. Cir. 1959); In re Santillanes, 47 N.M. 140, 151, 138 P.2d 503, 510 (1943). But see Antieau, Constitutional Rights in Juvenile Courts, 46 CoRNeL L.Q. 387, 389 (1961). 226 (1965).

25 See, e.g., McLaughlin \& McGee, Juvenile Court Procedure, 17 AlA. L. Rev. 26 See, e.g., AlA. Code tit. 13, $\$ 378$ (1959) ; D. C. Code ANN. $\$ 16-2308$ (Supp. V, 1966) ; N.J. REv. Stat. \$2A:4-39 (1952).

27 Under the D.C. Code, the juvenile court adjudication does not disqualify the minor from civil service positions. D.C. Code ANN. \$16-2308 (Supp. V, 1966).

28 See, e.g., McLaughlin \& McGee, supra note 25 , at $228-30$.

29 The hearing of all cases where children are involved shall be held at a different time from the hearing of other cases in the probate court. It shall be the duty of the judge of the court so to conduct the hearing as to disarm the fears of the child and to win its respect and confidence.

Ala. Code tit. 13, $\$ 353$ (1958). See Note, Juvenile Delinquents: The Police, State Courts, and Individualized Justice, 79. HARv. L. REv. 775, 790-91 (1966) [hereinafter cited as Harvard Research Project].

30 See Handler, The Juvenile Court and the Adversary System: Problems of Function and Form, 1965 WIS. I. REv. 7, 10; Rappeport, Determination of Delinquency in the Juvenile Court: A Suggested Approach, 1958 WASE. U.L.Q. 123, 161-62; Harvard Research Project 790-91. 
to be used in cases of repeated or serious offenders; ${ }^{31}$ and such incarceration is not imprisonment in an ordinary penal institution but placement in a juvenile hall for the purpose of rehabilitation. Although a modest trend in the direction of greater procedural protection may be discerned in recent years, many courts remain willing to write the Constitution out of juvenile proceedings except for the general prohibition against procedures which violate the "fundamental fairness" concept of due process, ${ }^{32}$ an injunction which has not proved effective.

Aside from rehabilitation, the desired product of the juvenile court process is the absence of the stigma usually attached to criminal conviction. ${ }^{33}$ It is rightly felt that no form of treatment can be effective if the minor, after an adjudication of delinquency, is disabled from assuming a normal role in society. Thus attempts are made to keep publicity at a minimum by eliminating the right to public trial ${ }^{34}$ and controlling the exposure of court records. ${ }^{35}$ The opinion of the court of appeals in Kent exemplifies the restrictive approach taken by some courts toward the control of court records. ${ }^{36}$ Beyond attempting to suppress publicity, juvenile court statutes generally do away with the official disabilities which ordinarily result from criminal conviction. ${ }^{37}$

Although it is difficult to argue with the genuine humanitarian goals of the juvenile court system, the disparity between the formulation of the ideal and the reality of the system is cause for great concern. The thesis

31 a) When the court finds that the child comes within the provisions of this subchapter... it may by order duly entered:

(1) place the child on probation or under supervision in his own home or in the custody of a relative or other fit person, upon such terms as the court determines;

(2) commit the child to the Board of Commissioners of the District of Columbia or its authorized representative; or to the National Training School for Boys if in need of such care as is given in the school; or to a qualified suitable private institution or agency willing and able to assume the education, care, and maintenance of the child without expense to the public; or

(3) make such further disposition of the child as may be provided by law and as the court deems to be best for the best interests of the child.

Paragraphs (1), (2), and (3) of this subsection do not authorize the removal of the child from the custody of his parents unless his welfare and the safety and protection of the public cannot be adequately safeguarded without the removal.

D.C. Code Ann. \$16-2308 (Supp. V, 1966).

32 See, e.g., Pee v. United States, 274 F.2d 556 (D.C. Cir. 1959); In re Santillanes, 47 N.M. 140, 138 P.2d 503 (1943). But see Kent v. United States, 86 Sup. Ct. 1045 (1966).

33 See notes $26 \& 27$ supra.

${ }^{34}$ See notes $73 \& 74$ infra and accompanying text.

35 See note 36 infra and accompanying text.

36 Kent v. United States, 343 F.2d 247, 257-58 (D.C. Cir. 1964). However, even before the Supreme Court reversed in Kent, the court of appeals had changed its attitude, evidencing great liberality in permitting inspection by the juvenile's attorney. See Watkins v. United States, 343 F.2d 278, 280-81 (D.C. Cir. 1964).

37 See, e.g., Ala. Cope tit. 13, § 378 (1958) ; D.C. Code ANn. \$16-2308 (Supp. V, 1966); N.J. Rev. Stat. § $2 A: 4-39$ (1952). 
of this Comment is that the procedural protections established to realize the goal of the system are inadequate and unfair. The starting point of analysis is the assertion that by changing the name of the proceedings and characterizing them as non-criminal we may not do away with the procedural protections afforded those who stand in jeopardy of being deprived of their liberty. While this idea is not new, and much of the material to be discussed concerning the current state of juvenile court law has been the subject of articles elsewhere, it is hoped that further elucidation will give support to a forthcoming proposal to incorporate procedural safeguards in the juvenile court scheme while preserving its basic goals. ${ }^{38}$

\section{The Current State of the Law}

\section{A. Jurisdiction}

Generally there are three types of cases brought before juvenile and family courts: dependency and neglect cases generally involving fault on the part of the parents; incorrigibility and waywardness cases which usually involve fault of the minor but where the acts committed do not rise to the status of crimes-e.g., cases involving truancy or association with undesirables; and delinquency proceedings involving acts which, if committed by an adult, would be considered crimes. ${ }^{39}$ It may well be that custody or wardship procedures are adequate in fact to deal with the first two categories of cases, although this problem is not dealt with here and no conclusions are offered. However, under most juvenile court statutes two or more of these types of cases are lumped under one jurisdictional section. Thus section 2A:4-14 of the New Jersey statute states:

[T] he juvenile and domestic relations court shall have exclusive jurisdiction to hear and determine all cases of juvenile delinquency.

Juvenile delinquency is hereby defined as the commission by a child under 18 years of age

38 The arguments made are avowedly one-sided in the sense that this Comment is devoted to advocating greater procedural protections in the juvenile courts, and the contrary position is not fully developed. It is felt that such development is not required because much has been written in legal journals concerning the reasoning behind establishing informal juvenile court procedures, see, e.g., Mack, The Juvenile Court, 23 Harv. L. REv. 104 (1910), and the body of case law is large. Thus, this Comment is conceived as merely an addition to a continuing dialogue concerning the efficacy of current juvenile court procedures and not as a complete statement of all the arguments which have been put forward either supporting or attacking those procedures.

Detailed discussion of the type of treatment dispensed by juvenile authorities will not be attempted, nor will there be an evaluation of the success of the methods utilized. The juvenile institutions of incarceration will not be examined except where necessary to demonstrate how the ideal departs from the actual. As a research tool, the juvenile court law of four jurisdictions was examined in depth: Alabama, California, District of Columbia and New Jersey. Cases and statutes from other jurisdictions are utilized to document specific points.

39 See, e.g., Ala. Code tit. 13, §350 (1958). 
(1) of any act which when committed by a person of the age of 18 years or over would constitute:

a. A felony, high misdemeanor, misdemeanor, or other offense, or

b. The violation of any penal law or municipal ordinance, or

c. Any act or offense for which he could be prosecuted in the method partaking of the nature of a criminal action or proceeding, or

d. Being a disorderly person, or

(2) of the following acts:

e. Habitual vagrancy, or

f. Incorrigibility, or

g. Immorality, or

h. Knowingly associating with thieves or vicious or immoral persons, or

i. Growing up in idleness or delinquency, or

j. Knowingly visiting gambling places, or patronizing other places or establishments, his admission to which constitutes a violation of law, or

k. Idly roaming the streets at night, or

1. Habitual truancy from school, or

m. Deportment endangering the morals, health or general welfare of said child. ${ }^{40}$

Similarly, section 350 of the Alabama code places the categories of "delinquent children," "neglected children" and "dependent children" under one jurisdictional section. ${ }^{41}$ The difficulty with not differentiating the jurisdiction of the courts over delinquency proceedings having criminal acts as their bases from their jurisdiction over wardship proceedings is the tendency to consider the same types of procedures adequate to deal with a variety of situations, some of which clearly are non-criminal in nature. While informal procedures may be sufficient in the case of a child who does not choose to go to school regularly, entirely different considerations should apply to the development of procedures to deal with a juvenile murderer. ${ }^{42}$ Legislatures may be reaching an awareness of this problem. The California juvenile court law, redrafted in 1961, differentiates among three

40 N.J. Rev. Stat. §2A:4-14 (Supp. 1965).

41 See note 39 supra.

42 See Rappeport, supra note 30, at 123-25. 
categories of cases, utilizing three distinct sections to define them. ${ }^{43}$ Throughout the act procedural requirements are established to deal separately with each of the three types of cases, and greater caution is employed when the case concerns offenses criminal in nature. ${ }^{44}$

A jurisdictional age limit of under eighteen years is most common for juvenile court statutes. ${ }^{45}$ Some courts interpret their statutes as requiring only that the juvenile have been under that age at the time of the alleged offense, while others hold that once the juvenile reaches eighteen the court loses its jurisdiction. ${ }^{46}$ However, the jurisdictional age limit is not universally set at eighteen. Alabama grants the juvenile courts exclusive jurisdiction only over minors under sixteen, ${ }^{47}$ but ordinary criminal courts are permitted to transfer sixteen or seventeen year old minors brought before them to the juvenile court if they deem such transfer "to be in the interest of justice and of the public welfare . . ." 48 Under

43 Any person under the age of 21 years who comes within any of the following descriptions is within the jurisdiction of the juvenile court which may adjudge such person to be a dependent child of the court:

(a) Who is in need of proper and effective parental care or control and has no parent or guardian, or has no parent or guardian willing to exercise or capable of exercising such care or control . . . .

(b) Who is destitute, or who is not provided with the necessities of life, or who is not provided with a home or suitable place of abode, or whose home is an unfit place for him by reason of neglect, cruelty, or depravity of either of his parents, or of his guardian or other person in whose custody or care he is.

(c) Who is physically dangerous to the public because of mental or physical deficiency, disorder or abnormality.

CAL. WeLfare \& Inst'NS CODE $\$ 600$.

Any person under the age of 21 years who persistently or habitually refuses to obey the reasonable and proper orders or directions of his parents, guardian, custodian or school authorities, or who is beyond the control of such person, or any person who is a habitual truant from school within the meaning of any law of this State, or who from any cause is in danger of leading an idle, dissolute, lewd, or immoral life, is within the jurisdiction of the juvenile court which may adjudge such person to be a ward of the court.

Cal. Welfare \& Inst'ns Code $\$ 601$.

Any person under the age of 21 years who violates any law of this State or of the United States or any ordinance of any city or county of this State defining crime or who, after having been found by the juvenile court to be a person described by Section 601, fails to obey any lawful order of the juvenile court, is within the jurisdiction of the juvenile court, which may adjudge such person to be a ward of the court.

CAL. Welfare \& INST'NS CODE $\$ 602$.

44 For example, to support a finding that a minor is a person described in $\S 602$, a preponderance of evidence legally admissible in the trial of a criminal case must be adduced, while in cases falling under $\$ \$ 600$ and 601 , a preponderance of the evidence legally admissible in civil cases must be adduced. CaL. Werfare \& INST'Ns Code $\S 701$.

45 E.g., D.C. Code Ans. \$§11-1551, 16-2301 (Supp. V, 1966) ; N.J. Rev. Stat. § 2 A :4-14 (Supp. 1965).

46 See Rappeport, sipra note 30 , at $139-45$.

47 AIA. CODE tit. 13, §350 (1958).

48 ALA. Code tit. 13, $\$ 363$ (1958). See Davis v. State, 259 Ala. 212, 66 Sò. $2 d$ 714 (1953), construing this provision and demonstrating the wide discretion lodged in the criminal court judge. 
California law the juvenile courts have jurisdiction of all criminal offenders under twenty-one, ${ }^{49}$ but they have exclusive jurisdiction only of those under eighteen at the time of the offense.50 In fact, rarely, if ever, are persons eighteen or over tried in the juvenile court, and the provision allowing certification to the juvenile court of those eighteen to twenty-one is apparently never exercised.

Although the problem of jurisdictional age limits is not the most crucial issue facing the juvenile courts, and the under eighteen cut-off seems perfectly reasonable, the experience in California concerning discretionary transfer would seem to demonstrate an important tendency on the part of regular judges dealing with the juvenile court system. It must be assumed that the legislature had some purpose in mind when it enacted the discretionary transfer section, yet the section has been totally ignored. Presumably this is in part due to a distrust by regular judges of the processes of the juvenile court, and is also partially attributable to the vagueness of the statute, which provides no standard to guide the exercise of discretion. ${ }^{51}$

\section{B. Pre-trial Practices}

There are two ways by which minors are brought under the processes of the juvenile court. After the police refer an alleged delinquent to the juvenile authorities, usually members of the social work or probation officer's staff, these authorities investigate the propriety of prosecuting an action against the minor. If they decide that further action is appropriate, a petition is filed in the juvenile court. ${ }^{52}$ The alternative route is certification from a regular criminal court, usually following discovery that the juvenile is within the age limits of exclusive juvenile court jurisdiction. ${ }^{53}$ Once the minor is brought under the court's jurisdiction, statutes, although sometimes in a sketchy manner, spell out procedures leading to a hearing and judgment. ${ }^{54}$ However, procedures to guide police in their handling of juveniles from the time of apprehension until the case is referred to the juvenile court officials are virtually non-existent. While a detailed discussion of police practices regarding juveniles will not be attempted, ${ }^{55}$ certain aspects of the relationship of the police to juveniles require mention.

49 See note 43 supra.

50 CAI. WeLFare \& INST'NS Code $\$ 604$ permits a judge of a criminal court to certify persons under twenty-one years to the juvenile court. However, minors eighteen or older are prosecuted in criminal courts as a matter of course. Harvard Research Project $793 \mathrm{n}$.83; Advisory Council of Judges, National Council on Crime and Delinquency, Transfer of Cases Between Juvenile and Criminal Courts: $A$ Policy Statement, 8 CRIME \& DeLINQUENCY 3, 8 (1962).

51 Section 604 states merely that a criminal court is permitted to certify transfer cases, but it offers no standard by which to decide when cases are to be certified.

62 See, e.g., D.C. Code ANN. \$16-2302 (Supp. V, 1966).

53 See, e.g., Ala. Code tit. 13, $\$ 363$ (1958); Cal. Welfare \& Inst'ns Code $\$ 604$.

64 For a statute establishing detailed procedures after referral, see CAL. WELFARE \& INST'NS CODE $\$ \S 624-64$.

55 This area was well described in the Harvard Research Project. 
Large numbers of juveniles apprehended by the police on suspicion of minor offenses are never brought under the juvenile court processes. A Harvard field study found that police operate ad hoc juvenile court hearings, releasing confessed violators with only an admonishment. ${ }^{56}$ The threat of referrals is used to induce confession. Thus, the juvenile court never deals with the great mass of offenders. Presumably the serious offenders and those who do not confess are referred to the juvenile court authorities. The problem of coerced or illegal confessions obtained from serious offenders during the period from apprehension to referral is of greatest concern.

The most concrete evidence of coercive police practices is the extraordinary number of confessions given in the station house; ${ }^{57}$ it has been estimated that in ninety-nine per cent of juvenile court cases the suspect has made a confession. In 3,000 consecutive cases in one court over a two year period only five accused juveniles wholly denied involvement, 58 although this figure may include some who admitted guilt at the hearing without having given a prior confession to the police. Presently, the importance of illegally obtained confessions is not as great as might be felt initially, since most juveniles apparently also admit involvement at the hearing - the juvenile equivalent to a guilty plea. Only where the juvenile recants from a confession given to the police is the issue of illegal confessions brought into focus. As the incidence of representation of juveniles by counsel increases, fewer guilty pleas may be expected, and standards governing the admissibility of confessions may become the most crucial issue facing the juvenile courts.

No definite answer may be offered to the question whether these confessions are the result of superior police investigation or police overbearing. However, one can point with certainty to the fact that the protections against coerced confessions are substantially fewer than in an adult court. No provision is made for a pre-trial hearing to suppress coerced confessions, as is provided in federal and most state jurisdictions. And even if there were, the infrequency of representation by counsel ${ }^{59}$ would severely hamper the juvenile in his attempt to exclude the confession. Under present procedures the juvenile's claim of coercion raises an issue of fact to be decided at the hearing. ${ }^{60}$

The strongest argument against the need for greater protections from coerced confessions proceeds from the observation that juveniles are not tried before juries, and a judge will be able to exclude an unreliable confession from his mind when making his factual findings. There are several reasons why this suggestion does not offer the juvenile sufficient protection. While it is true that an appellate court will not uphold a judgment based

56 Harvard Research Project 780-81.

57 See Handler, supra note 30, at 19; Harvard Research Project 779-81, 794.

58 Handler, supra note 30 , at 19.

59 See note 83 infra and accompanying text.

60 See Robinson v. State, 204 S.W.2d 981 (Tex. Civ. App. 1947). 
solely on a coerced confession, the nature of the appellate process makes it difficult to demonstrate actual reliance by the lower court judge if the record contains other supporting evidence. Thus, in a case where the evidence aside from the coerced confession is not conclusive, there is always a danger that the unlawful confession may have actually convinced the court, yet if the other evidence is substantial, appellate courts apparently will not reverse. ${ }^{.1}$ Under normal criminal procedure the defendant has a means of substantially removing this danger-the right to demand trial by jury. The Supreme Court has required the states to provide procedures whereby a confession attacked by the defendant will not be placed in evidence before the jury until the question of legality is decided by the judge. ${ }^{62}$ Thus the trier of fact is never exposed to a coerced confession. The juvenile offender is not granted this protection because he generally has no right to trial by jury. ${ }^{83}$

While there are great barriers facing the juvenile attempting to prove his confession was coerced, at least the courts have recognized that confessions proven coerced should not be given probative weight by the trier of fact. The same may not be said of confessions obtained under circumstances not truly coercive which would normally cause the confession to be suppressed under interpretations of the federal or state constitutions. Case law in this area is sparse, presumably because of the general belief that juvenile courts are non-criminal and that constitutional protections accorded criminal defendants are not relevant. Coerced confessions as a matter of evidence are considered unreliable and therefore are to be given no weight, but such is not the case where the confession would be admitted in a criminal trial but for a violation of the rule of Miranda $v$. Arizona. ${ }^{64}$ Because it has been held that no constitutional issue is present, confessions which are the product of police illegality are admissible and are given full weight because there is little question of their reliability as a matter of evidence. Under this analysis, a Texas court held that a confession obtained while the minor was illegally under arrest and not advised of his right to counsel as required by Texas law was not suppressible on those grounds alone, and proof of actual coercion was required..$^{65}$

The problem of excluding illegal confessions is more acute than that faced when we are dealing with coerced admissions, since illegal confessions, once admitted, are reliable evidence. One of the important bases for excluding confessions in criminal cases where the defendant was deprived of his constitutional rights, as under the Miranda rule, is the suppression

${ }^{61} C$ f. notes 138-40 infra and accompanying text.

62 See Jackson v. Denno, 378 U.S. 368 (1964).

63 See notes $77 \& 78$ infra and accompanying text.

6434 U.S.L. WEEK 4521 (U.S. June 13, 1966).

65 This being a civil proceeding, it was immaterial whether he was under arrest, legal or illegal, at the time the confession was made. While there was some evidence that coercion or intimidation was used in its procurement; such evidence was sufficient only to raise a fact question on that issue.

Robinson v. State, 204 S.W.2d 981, 982 (Tex. Civ. App. 1947). 
of illegal police practices. It seems strange indeed that adult criminal offenders are given great protection while their younger counterparts receive little. Beyond this it must be considered that the decision to admit a confession may be the most crucial question in a criminal trial or a juvenile court hearing. Constitutional strictures are placed on police practices relating to the procurement of confessions so that fairness to the alleged criminal offender will be guaranteed. In the area of coerced confessions, procedural protections are established for fear that without them the innocent may be convicted. Much of the law concerning restrictions on the admissibility of illegal confessions may be explained in terms of protecting the defendant from confessions obtained under circumstances where coercion may be likely but where it would be difficult, if not impossible, to prove coercion. The fear of admitting these types of confessions should be no less real in the juvenile court and the procedural restrictions no less stringent. ${ }^{66}$

Problems concerning illegal searches and seizures have almost never been litigated in the juvenile court context. This may be explained by the frequency of confessions and the general belief that constitutional standards concerning search problems do not apply in such courts. However, a New York court has recently said that such standards, including the exclusionary rules, do apply in the juvenile court. ${ }^{67}$ The D.C. Circuit has held that the Federal Rules of Criminal Procedure do not apply to juvenile court proceedings, ${ }^{68}$ but it is not clear whether the court meant to exclude additionally the body of law concerning illegal searches and seizures. If greater restrictions are placed on the use of confessions, and especially if juries become more common in juvenile court cases, additional problems may be expected in this area.

\section{The Hearing Process}

Earlier the justifications for informality in the hearing process were discussed. The arguments put forward for informality-expedited fact-

60 The recent New York Family Court Act provides new protection against the indiscriminate use of confessions:

(b) Any determination at the conclusion of an adjudicatory hearing that a respondent did an act or acts must be based on a preponderance of the evidence. For this purpose, an uncorroborated confession made out of court by a respondent is not sufficient.

N.Y. FAMmY CT. ACT $\$ 744$ (b).

6i I can think of few worse examples to set for our children than to visit upon children what would be, if they were older, unreasonable and unconstitutional invasions of their all-too-limited privacy and rights, merely because they are young. In this sense, our proceedings are not "civil." They are perhaps, for this purpose, "quasi-criminal" in character. . . Young persons have the same constitutional rights as older ones in delinquency and supervision jurisdiction, except the right to a jury trial . . .

In the Matter of Ronny, 40 Misc. 2d 194, 210, 243 N.Y.S.2d 844, 860 (Family Ct. $1963)$.

68 Harling v. United States, 295 F.2d 161, 163 (D.C. Cir. 1961) ; Pee v. United States, 274 F.2d 556, 559 (D.C. Cir. 1959); United States v. White, 153 F. Supp. 809 (D.D.C. 1957). 
finding, the therapeutic value to the minor of informal hearings and the absence of the traumatic experience inherent in an ordinary criminal trial, and its attendant stigma of criminality-have carried the day. Before challenging the validity of these assumptions, an examination of the effect informality has had on the hearing and fact-finding process will be made to determine, conceding the arguments for informality to be valid, whether on balance they are outweighed by the detrimental effects which also flow from informal procedures. While so doing, it is important to note that there is a slight trend away from informality which will be subsequently examined.

The basis for informal hearings is usually statutory. An extreme example is the admonishment contained in the Alabama code: "It shall be the duty of the judge of the court so to conduct the hearing as to disarm the fears of the child and to win its respect and confidence." ${ }^{\circ 9}$ More common is the direction to conduct the hearing in an informal manner or not to conduct it as a criminal trial. ${ }^{70}$ However, a significant step was taken in the drafting of the new California code which states: "Except where there is a contested issue of fact or law, the proceedings shall be conducted in an informal non-adversary atmosphere with a view to obtaining the maximum cooperation of the minor upon whose behalf the petition is brought . . . "71 Coupled with liberal provisions providing for appointment of counsel, ${ }^{72}$ this section may represent the germinal development of formal, adversary criminal trials in the juvenile court.

\section{Public Trials}

It is almost universally accepted that there is no right to public hearings in juvenile courts. ${ }^{73}$ Statutes generally provide that only persons having a direct interest in the case and officials of the court may be present at the hearings. Some jurisdictions also permit the judge to open the hearing to "such other persons as he deems to have a legitimate interest in the case or the work of the court." 74 The justification for dispensing with the right to public trial is usually said to be the protection of the child. It is a means of suppressing publicity during the adjudication and thereby limiting the stigma of criminality. Another possible reason is that public

69 Ala. CoDE tit. 13, 353 (1958).

70 D.C. COde ANN. $\$ 16-2307$ (Supp. V, 1966) (hearings may be conducted in an informal manner); N.J. Rules $6: 9-3-$ (c) (hearing shall not be conducted as criminal trial).

71 CAL. Welfare \& IasT'NS CODE $\$ 680$. (Emphasis added.)

72 Cal. Welfare \& INST'NS CODE $\$ \$ 633,658,659,700$.

${ }^{73}$ AlA. Cope tit. 13, $\$ 353$ (1958) ; D.C. CoDE ANN. \$16-2307 (Supp. V, 1966;

N.Y. FAMITY C. ACT \$742; N.J. Rules 6:9-3-(c).

74 The general public shall be excluded from the hearing and only such persons as have a direct interest in the case and their representatives may be admitted except that the judge presiding at the hearing, by rule of court or special order, may admit such other persons as he deems to have a legitimate interest in the case or the work of the court.

D.C. Code Ann. \$16-2307 (Supp. V, 1966). 
pressure will not so readily be brought to bear on the court to deal harshly but unwisely with serious offenders. The thought is that behind closed doors the informal procedure will work quietly and effectively.

While there may be validity to the fears that open hearings with attendant publicity could stigmatize the juvenile as a criminal, thus severely hampering his efforts to reenter society, there are other considerations which should be taken into account before public trials for juveniles are blithely eliminated. Most courts would dismiss the constitutional questions, stressing the non-criminal nature of juvenile court proceedings. But this argument does not answer the questions raised by the policies underlying the right to public trial. In a system which exalts informality, where procedural protections are slim, the danger of "star chamber" proceedings removed from public scrutiny is substantial. ${ }^{75}$ Under present law there is no way in which the juvenile can protect himself from non-public injustice in the juvenile court. The exception to the rule is the California code which provides for a private hearing unless the juvenile or his parent or guardian requests that the proceeding be public. ${ }^{76}$ The California solution, while in theory granting the juvenile a right to public trial, unfortunately places on him the burden of asking for it. By requesting an open hearing the juvenile may in effect be voicing a fear as to the fairness of a private proceeding conducted by the presiding judge. It is doubtful that many litigants in the juvenile court would request a public hearing at the risk of having such a request interpreted as a criticism of the presiding judge. If instead legislatures provide a waivable right to public proceedings rather than public proceedings on request, most of the concerns mentioned above would be satisfied. Those who fear closed-door treatment automatically would be granted a public trial, while if it is felt that publicity resulting from the hearing would jeopardize the juvenile's chances for reentering society, a private hearing may be requested.

\section{Trial by Jury}

The prevailing opinion at the present time is that there is no constitutional right to jury trial in juvenile courts, ${ }^{77}$ and the great majority of statutes do not make provision for juries. ${ }^{78}$ Apparently, this is felt to be

75 For an illustration of this danger, see Green v. State, 123 Ind. App. 81, 108 N.E.2d 647 (1952).

76 CAL. WeLfare \& INST'NS Code $\$ 676$.

77 Ex parte State ex rel. Echols, 245 Ala. 353, 356, 17 So. 2d 449, 450 (1944); People $e x$ rel. Weber v. Fifield, 136 Cal. App. 741, 289 P.2d 303 (1955); Wissenberg v. Bradley, 209 lowa 813,229 N.W. 205 (1930); Bryant v. Brown, 151 Miss. 398 408, 413-14, 118 So. 184, 186, 187-88 (1928). In the Matter of Ronny, 40 Misc. 2d 194, 242 N.Y.S.2d 844 (Family Ct. 1963), held that minors before the juvenile court have the same constitutional rights as adults except for the right to trial by jury, "which is balanced by our circumscribed power and the confidentiality here maintained in an effort to keep the record of a child unblemished." Id. at 210, 242 N.Y.S.2d at 860.

78 New Jersey law specifically provides for hearings in the juvenile court without jury, N.J. REv. STAT. $\$ 2 A: 4-35$ (1952), and if a minor of sixteen or seventeen demands jury trial, the case is referred to the prosecutor for regular criminal proceedings. N.J. REv. Stat. \$2A:4-15 (1952). 
consistent with the desired informal procedures; even California, a jurisdiction which has retreated somewhat from informality, makes no provision for trial by jury. The District of Columbia is a notable exception. Its statute provides: "The court shall hear and determine all cases of children without a jury unless a jury is demanded by the child, his parent, guardian, or the court." 79 Especially significant is the provision whereby the court itself may provide for a jury trial, a provision which could be helpful in cases of younger children or minors with lower intelligence charged with serious offenses and those who are orphans or whose parents are uninterested. However, the entire jury provision has been given a crippling interpretation by the Municipal Court of Appeals. ${ }^{80}$ In a proceeding where two infants were found to be without adequate parental care and were committed to the Board of Public Welfare, a parent assigned as error the refusal of the juvenile court to grant a request for a jury trial. The municipal court affirmed, finding no constitutional right because the proceeding was non-criminal and not at common law. Interpreting the statute, the court said:

If the statute, as some statutes do, clearly gives the right to a jury trial, then of course the court would have no right to deny it. However, our statute does not clearly say that the right to jury trial shall be had in all cases of children. It specifically says trial shall be without a jury "unless a jury be demanded by the child, his parent, or guardian or the court." We do not believe that Congress intended in this indirect way to make a sweeping grant of the right of jury trial to all persons involved in cases involving children. Had it intended to make so drastic a change, we feel it would have said so in a plainer and more direct manner .... Our conclusion is that the statute did not enlarge the right to trial by jury but only preserved it where a constitutional right to jury trial exists, provided seasonable demand therefor is made. ${ }^{81}$

The dissent called this a judicial repeal. ${ }^{82}$ Because it is generally held that there is no constitutional right to trial by jury in the juvenile court, the court's analysis is the equivalent of stating that there is no right to jury trial under the statute. Apparently because of the large number of confessions given at hearings, the need for jury trials has not seemed acute, and there is no reported instance where a litigant has challenged the municipal court's interpretation.

Apart from the question of constitutional requirements, trial by jury should be provided as a matter of policy for those who desire it as a pro-

79 D.C. Code Ann. \$16-2307 (Supp. V, 1966) ; see AlA. Code tit. 13, § 354 (1958).

80 In re Lambert, 86 A.2d 411 (D.C. Munic. Ct. App. 1952).

81 Id. at 412 .

82 Id. at 414. 
tection against jaded judges who hear case after case, day in and day out, and decide on past prejudices rather than present evidence. Also present is the previously discussed problem of excluding illegal or coerced confessions. Under current procedures the same judge who must decide the case is also asked to rule on the legality of the confession. Of course, in an ordinary criminal case tried by a judge without jury, he might be asked to do the same thing. But in a criminal case the defendant chooses whether trial will be by jury. If he fears prejudice in having the trier of fact hear the confession, even if it is eventually proved illegal, he may protect himself by asking for a jury. The danger of this kind of prejudice would seem to be most substantial where the litigant does not claim actual coercion but merely that the confession was obtained under illegal circumstances. This problem could be solved by the use of pre-trial procedures to exclude illegal confessions, using a system of rotating judges so that the same man does not sit on both the pre-trial and the fact-finding hearings. Of course in the many areas where there are only one-judge juvenile courts, judges from the regular legal system would be required to hear the pre-trial claims concerning illegal confession. The need for these complicated procedures could be obviated by offering trial by jury. It should be noted also that while a two-judge procedure could effectively exclude an illegal confession from consideration by the trier of fact, it does not satisfy the concern raised about prejudiced or jaded judges.

\section{The Right to Counsel}

It is in the area of right to counsel that the developments in the law of juvenile courts have been most striking. In the majority of juvenile court cases, probably in the vast majority, the minor is not represented. ${ }^{83}$ However, in some jurisdictions, both by statute and case law, the right to counsel is being granted the criminal offender in the juvenile court. These developments are not particularly surprising because of the extreme disability facing minors trying to defend themselves without aid in a court of law. ${ }^{84}$

83 In most of the courts studied in the Harvard Research Project, attorneys appear for juveniles in no more than $5 \%$ of the cases. However, a Boston judge estimated that minors were represented in $35 \%$ to $40 \%$ of juvenile court cases. In San Francisco it was estimated that attorneys were present in $30 \%$ of the cases, but this figure is probably explained by the liberal provisions of the California code relating to appointment of counsel. In New York, since the introduction of the law guardian system under the new Family Court Act, attorneys are present in the great majority of cases.
Harvard Research Project 796.

84 In re Mikkelsen, 226 Cal. App. 2d 467, 38 Cal. Rptr. 106 (1964), demonstrates one of the pitfalls faced by a minor before the court who was represented by counsel. At the hearing, the minor's counsel and psychiatrist were present. After the clerk read the allegations in the petition charging the minor with wilful and lewd exposure of "his person and private parts in the presence of others ...." the minor in response to the judge's question admitted the truth of the facts stated. 'The court then stated, "The petition is sustained," followed by counsel's objection: "We don't intend to waive the right to have evidence introduced. I think that [the minor]... admits that he exposed himself. Now, lewdly, and the different parts of it, $\ddot{I}$ don't know that that is the fact but the physical facts happened and we want to cooperate with 
Preliminarily, it must be noted that the government is frequently without the services of counsel in juvenile court cases. Without the presence of lawyers the hearing takes on a decidedly non-adversary aspect. As has been pointed out, most juveniles confess, and once guilt is admitted the hearing is over. ${ }^{85}$ When the juvenile denies guilt in some jurisdictions the judge assumes the role of prosecutor, defense attorney and finder of fact; in questioning the juvenile from the bench he must determine the validity of the petition, safeguard the child's rights, such as they are, and make a final judgment. ${ }^{80}$ Recognizing that such a system makes the judge's prime function-that of fact finder-much more difficult, various alternatives have been utilized: the probation officer working with the juvenile does the questioning, or a representative of the police may be present. 87 He may be the officer who arrested the minor, a special prosecuting officer of the juvenile division or police counsel. In a few jurisdictions a representative of the district attorney's office tries juvenile court cases. ${ }^{88}$ Regardless of the alternative used, the juvenile charged with a criminal act requires counsel fully to protect his rights and to mount an adequate defense. $^{89}$ The need is underscored when the extremely large number of confessions given to the police by juveniles is recalled, for without counsel the chance of a youth under eighteen proving his confession coerced or illegal seems nil.

In the appointment of counsel for indigent juvenile criminal offenders, two of the most advanced jurisdictions are New York and California. Under the New York law guardian system, established by the Family Court Act of 1962, on request of the minor or his parents or guardian the court must appoint counsel if the minor is not independently able to retain a lawyer..$^{00}$ The act requires informing the minor or parent of the right

your procedures but we don't want to waive any rights we may have, is all." The judge immediately responded, "The petition is sustained and wardship is declared." Id. at 469,38 Cal. Rptr. at 108.

Apparently the juvenile court judge acted on the notion that admission of the facts of a petition constitutes a guilty plea, even though counsel was attempting to put in a defense. The appellate court reversed, finding it a violation of due process to deprive the minor of the right to introduce evidence. Ibid. However, without counsel this objection probably never would have been raised, and even with counsel present, it required an appellate court decision before a defense was permitted to be raised.

85 This rule is demonstrated in In re Mikkelsen, supra note 84 . See In re Patterson, 58 Cal. 2d 848, 377 P.2d 74, 27 Cal. Rptr. 10 (1962) (admission of the charges equivalent to a guilty plea).

${ }^{86}$ See N.J. Rules 6:9-1(c) ; Harvard Research Project 795-96.

87 Ibid.

88 Ibid. New Jersey provides prosecutors in homicide cases. N.J. RuLEs 6:9-1 (g).

89 See note 84 supra.

90 N.Y. FAMnIY CT. ACT $\$ \$ 241-49$. It has been suggested that an attorney appointed to represent a juvenile before the family court may not be placed in a purely adversary role. For example, the best interests of the child may dictate that an attorney disclose evidence adverse to his client or that a particular right not be asserted in every instance. See Dembitz, Ferment and Experiment in Neze York: Juvenile Cases in the New Family Court, 48 CoRNELI I.Q. 499, 508-11 (1963). However, a conversation with a staff member of the Law Guardian Division of the New York Legal Aid Society revealed that such suggestions have not been followed and appointed counsel under the New York act assume an adversary role. 
to counsel ${ }^{91}$ and permits the court on its own motion to make an appointment without request. ${ }^{22}$ Under California law if the minor, parent or guardian desires counsel and is indigent, the court must make an appointment if the juvenile is charged with a criminal act which if committed by an adult would be considered a felony, and in all other cases the court may appoint counsel if requested. ${ }^{93}$ In cases where a conflict of interest appears between parent and child, the court may make additional appointments. ${ }^{\text {94 }}$

Without statutory provision the juvenile has been hard pressed in his attempts to convince the courts that he should be given a right to counsel. The experience in California prior to the new code is instructive. In re Contreras, ${ }^{95}$ decided in 1952 , seems to be the first decision under modern California law holding that a juvenile has a right to counsel in a juvenile court. Contesting the denial of his motion to appoint counsel, Contreras appealed an order of the juvenile court finding him to be a juvenile delinquent on a charge of assault with a deadly weapon and committing him to a juvenile institution. A state court of appeals, in reversing the judgment, held that it was an abuse of discretion to deny the motion, on two grounds: the transcript contained evidence admitted during the hearing which the court felt could have been excluded by objection at trial, and the litigation in the juvenile court resulting in the deprivation of liberty was indistinguishable from a criminal action where the right to counsel is preserved. ${ }^{96}$ However, three years later another California court refused to reverse a finding of delinquency and order of commitment because of a failure to appoint or notify of the right to counsel. ${ }^{97}$ The ground of decision was the "non-criminal" rubric, and Contreras was distinguished as reversing the lower court because it had acted "entirely on incompetent evidence." 98

91 N.Y. FAMILY CT. AcT $\$ 741$.

92 N.Y. FAMILY CT. ACT $\$ 249$.

93 CAL. WELFARE \& INST'NS CODE $\$ 634$. The minor or his parent must be informed of the right to counsel. CAI. WELFARE \& INST'NS CODE $\$ \$ 633,700$; see In re Patterson, 58 Cal. 2d 848, 377 P.2d 74, 27 Cal. Rptr. 10 (1962). Appointed counsel is awarded reasonable compensation paid out of a county general fund. CAL. WeLFARE \& INST'NS CODE $§ 517$.

94 Cal. Welfare \& INST'NS Code $\$ 634$.

95109 Cal. App. 2d 787, 241 P.2d 631 (1952).

96 Countering the claim that there is no right to counsel in the juvenile court because of the non-criminal nature of the adjudication, the court said:

It is common knowledge that such an adjudication when based upon a charge of committing an act that amounts to a felony, is a blight upon the character of and is a serious impediment to the future of such minor. Let him attempt to enter the armed services of his country or obtain a position of honor and trust and he is immediately confronted with his juvenile court record. And further, as in this case, the minor is taken from his family, deprived of his liberty and confined in a state institution. True, the design of the Juvenile Court Act is intended to be salutory, and every effort should be made to further its legitimate purpose; but never should it be made an instrument for the denial to a minor of a constitutional right or of a guarantee afforded by law to an adult.

Id. at 789-90, 241 P.2d at 633 .

97 People ex rel. Weber v. Fifield, 136 Cal. App. 2d 741, 289 P.2d 303 (1955). 98 Id. at 743, 289 P.2d at 305. 
This, of course, was a clear misrepresentation of the grounds of decision in Contreras. The reference to evidence in that case was merely that evidence was introduced which could have been excluded by counsel's objection, not that there was no competent evidence. The second ground of decision in Contreras was basically ignored, although implicitly rejected, in the later case. During the next year Contreras was again shoved aside in People v. Dotson, ${ }^{99}$ a waiver of jurisdiction case. Again the supposed non-criminal nature of juvenile court proceedings was given as justification for refusal to appoint counsel. Contreras was again distinguished but not on the evidence ground alone. The appellate court felt that because Contreras dealt with a dispositive hearing, resulting in the deprivation of the juvenile's liberty, it was distinguishable from the case before it where guilt was not at issue and the only question was whether the minor was a fit subject for juvenile court action.100 Apparently not considered was the fact that following waiver Dotson was tried and convicted of murder in a regular court, and he claimed not to have resisted waiver because he never understood what was at stake. Dotson was followed by In re Garcia, ${ }^{101}$ decided in 1962, involving a judgment of delinquency based on the commission of a homicide. In refusing reversal the court merely announced that the denial occurred at a hearing which took place before the 1961 act was passed and that there is no constitutional requirement that counsel be appointed in juvenile court. Such was the state of California law prior to legislative revision.

In the District of Columbia the first breakthrough came in Shoutakon v. District of Columbia, ${ }^{102}$ decided in 1956. A judgment of juvenile delinquency for auto theft and a commitment to a training school was set aside by the D.C. Circuit for failure to advise of the right to counsel or to appoint counsel. However, the court declined to base its decision on constitutional grounds, limiting itself to a construction of the statute.

The serious nature and effect of this adjudication suggests that Congress could not have been unaware of the need for effective assistance of counsel. Although that Act in terms neither recognizes nor withholds such assistance, the legislative history reflects congressional understanding that alleged delinquents would be represented by counsel. . . . The "right to be heard" when personal liberty is at stake requires the effective assistance of counsel in a juvenile court as much as it does in a criminal court. ${ }^{103}$

It should not go unnoticed that during the previous year it was held in a much ignored district court opinion, In re Poff, ${ }^{104}$ that due process requires

9946 Cal. 2d 891, 299 P.2d 875 (1956).

$100 \mathrm{Id}$. at $895-96,299$ P.2d at 878 .

101201 Cal. App. 2d 662, 20 Cal. Rptr. 313 (1962).

102236 F.2d 666 (D.C. Cir. 1956).

103 Id. at 669 .

104135 F. Supp. 224 (D.D.C. 1955). 
that a juvenile must be advised of his right to counsel whenever he is charged with an offense before the juvenile court which "if committed by an adult would constitute a crime . . . "105 In 1960 the Legal Aid Act was passed requiring the Legal Aid Agency to make attorneys available to represent indigents "in proceedings before the juvenile court . . . ."108 A recent case has interpreted this statute to require appointment of counsel to represent a minor while the juvenile court is deliberating whether it should waive its jurisdiction. ${ }^{107}$

Other jurisdictions are not so advanced. Under the rules governing the New Jersey courts a juvenile is entitled to be represented by counsel at every stage of the proceedings, ${ }^{108}$ but in the case of indigents the court is required to appoint counsel only in homicide hearings $;^{109}$ in all other cases discretion is lodged with the juvenile court judge to appoint counsel "where necessary for a fair hearing . . . ."110 While "attornies have always been welcome in the Calhoun City Juvenile Court," 111 Alabama makes no provision for the appointment of counsel to represent indigent juveniles before its juvenile courts. The court has discretion to call in lawyers to assist in the proceedings, but it seems to be exercised only in bastardy cases. ${ }^{112}$

Lest one become overly encouraged by recent developments, a 1962 California Supreme Court case decided after the new act became law is a poignant reminder that great battles are not easily won in the juvenile court area. ${ }^{113}$ Section 633 of the act requires that when a minor appears at a pre-trial detention hearing he, and his parent if present, be informed of the right to counsel. Section 658 provides that notice of the hearing on the petition must be served upon the minor's parents, and section 659 requires notice that the parent is entitled to have an attorney present and, if indigent, to have counsel appointed if desired. Section 700 provides that at the beginning of the fact-finding hearing the judge shall ascertain whether the minor or his parent has been informed of the right to counsel

$105 \mathrm{Id}$. at 227 . It has also been held that a waiver of counsel must be intelligently made. "The latter implies that where a waiver is relied on, the Juvenile Court must affirmatively find as a fact that by reason of 'age, education, and information, and all pertinent facts' the minor is able to and did make an intelligent waiver." McBride v. Jacobs, 247 F.2d 595, 596 (D.C. Cir. 1957). Thus some minors are incapable of waiving, and where this is so the parent may waive provided there is no conflict of interest between the minor and his parent. Ibid. 108 D.C. CODE ANN. \$ 2-2202 (1961).

107 Black v. United States, No. 19038, D.C. Cir., Dec. 8, 1965. At the time of decision, no hearing was required before waiver.

108 N.J. Rules 6:9-1.

109 N.J. RULES 6:9-1(b).

110 N.J. Rules 6:9-1(a). State v. Tuddles, 38 N.J. 565, 186 A.2d 284 (1962), held that in cases involving homicides the court must grant a juvenile's request to be represented during waiver proceedings. See State v. LaPierre, 39 N.J. 156, 188 A.2d 10, cert. denied, 374 U.S. 852 (1963). (1965).

111 McLaughlin \& McGee, Juvenile Court Procedure, 17 ALA. L. REv. 226, 239

112 Id. at 238.

${ }^{113}$ In re Patterson, 58 Cal. $2 \mathrm{~d}$ 848, 377 P.2d 74, 27 Cal. Rptr. 10 (1962), cert. denied, 374 U.S. 838 (1963). 
and, if not, shall so advise them. In re Patterson construed these sections for the first time. The minor appealed a judgment declaring him a ward of the court and committing him to the youth authority for entering a residence with intent to commit a theft. His appeal was based on the failure of the juvenile court judge to advise him or his mother of the right to counsel at the beginning of the fact-finding hearing under section 700 . The records before the juvenile court judge at the beginning of the hearing revealed the following facts: after the minor was taken into custody he received a detention hearing, and an affidavit of a referee stated that the minor was then advised of his right to counsel. The minor's mother was not present at the detention hearing, but she was given written notice of the hearing advising her of her right to have counsel appointed; she never requested such appointment. The court affirmed the judgment, holding that the juvenile court judge was "advised" that the minor and his mother had been informed of their right to counsel from the records before him, and that once the judge had ascertained from the records that the minor and his parent had been informed of their rights, he was justified in proceeding without again advising them. The duty would have devolved on him only had the record not shown that they had previously been informed. The court further rejected the minor's contention that section 700 required appointment in all cases where indigent juveniles were charged with conduct which would constitute a felony if committed by an adult. Appointment was held mandatory only after request. Chief Justice Traynor, joined by two other justices, dissented, pointing out that the majority's interpretation made section 700 practically superfluous. ${ }^{114}$ The juvenile court judge would now be permitted to ascertain whether the minor or his parents had been informed of the right to counsel simply by examining the record. No requirement was established that he must note in the record that he ever made such an examination, nor did the majority require him to determine the accuracy of the record or whether the absence of counsel was the result of an intelligent waiver. It need not even be determined that the mother read the notice sent her or that she was able to read.

\section{Evidentiary Problems}

Perhaps the most vexing problems in the operation of juvenile court hearings occur in the process of fact-finding. The concept of informal procedures and the notion that the hearing is really a "search for the truth" ${ }^{110}$ have led to the idea that the strict rules of evidence ought not

114 Id. at 853-57, 377 P.2d at 77-78, 27 Cal. Rptr. at 13-19.

115 This is not to say that regular criminal trials are not also searches for the truth. However, ordinary criminal procedures place restraints on this search to protect the defendant. Thus, he may not be forced to answer a question which would incriminate him, strict rules of evidence bar the hearing of certain types of statements, confessions obtained under illegal circumstances are not admissible, and illegally seized evidence is disallowed. These protections either do not exist in the juvenile court or exist only in a modified form. 
to apply in juvenile courts. The effect such assertions have had on the juvenile court fact-finding process will be a source of later discussion; however, it must be remembered that claims of rehabilitative function or non-criminality do not obviate the need to prove the fact that the juvenile actually committed an offense listed in the jurisdictional section in order to bring him under the processes of the juvenile court. Hopefully, the offense will be proven in a legally reliable manner.

\section{a. Burden of Proof}

Even though juvenile court litigation may result in deprivation of liberty, most courts and legislatures reaching the question have not required that the criminal law burden of proof be applied.116 New York, for example, had seemed to be leaning toward the requirement of proof beyond a reasonable doubt; ${ }^{117}$ however, the 1962 Family Court Act resolved the question in favor of a "preponderance of the evidence" standard. ${ }^{118}$ The requirement of only a preponderance of the evidence is usually justified on the grounds that juvenile court adjudication is not criminal litigation; being adjudged a delinquent does not carry, at least officially, the stigma of criminal conviction; and imprisonment in a penal institution, as a punishment, is not permitted under juvenile court law. ${ }^{119}$ Thus the added protection given to a criminal defendant by placing a strict burden of proof on the state is not required in this context. These arguments have been flatly rejected by the Supreme Court of Virginia. In Jones $v$. Commonwealth, ${ }^{120}$ requiring proof beyond a reasonable doubt, that court stated:

The judgment against a youth that he is a delinquent is a serious reflection upon his character and habits. The stain against him is not removed merely because the statute says no judgment in this particular proceeding shall be deemed a conviction for crime or so considered. The stigma of conviction will reflect upon him for life. It hurts his self-respect. It may, at some inopportune, unfortunate moment, rear its ugly head to destroy his opportunity for advancement, and blast his ambition to build up a character and reputation entitling him to the esteem and re-

116 See, e.g., In re Bigesby, 202 A.2d 785 (D.C. Ct. App. 1964) ; State v. Ferrell, 209 S.W.2d 642 (Tex. Civ. App. 1948); cf. Cantu v. State, 207 S.W.2d 901 (Tex. Civ. App. 1948).

Apparently, some judges establish standards for their own court, such as requiring "clear and convincing" proof, and some judges in jurisdictions requiring a lesser burden of proof utilize the "proof beyond a reasonable doube" standard. Harvard Research Project 795.

117 See In re Madik, 233 App. Div. 12, 251 N.Y. Supp. 765 (1931) ; In re Rich, 86

N.Y.S.2d 308 (Dom. Rel. Ct. 1949).

118 N.Y. FAMILY CT. ACT $\$ 744(\mathrm{~b})$. See In the Matter of Ronny, 40 Misc. 2d 194, 197, 242 N.Y.S.2d 844, 848 (Family Ct. 1963).

110 See In re Bigesby, 202 A.2d 785 (D.C. Ct. App. 1964); State ex rel. Berry v. Superior Court, 139 Wash. 1, 245 Pac. 409 (1926).

120185 Va. 335, 38 S.E.2d 444 (1946). 
spect of his fellow man. . . . Guilt should be proven by evidence which leaves no reasonable doubt. Inference must give way when in conflict with facts established by positive proof. ${ }^{\mathbf{1 2 1}}$

However, the recent revisions in New York and California, ${ }^{122}$ both adopting the lesser burden, seem to indicate that legislatures are not yet willing to accept the argument that juvenile courts are, in substance if not in form, acting as criminal tribunals in delinquency litigation. This is unfortunate in that one of the most basic protections afforded those who are in jeopardy of being deprived of their liberty following alleged commission of criminal acts is that the proof of the act must be beyond a reasonable doubt. Additionally, a stricter burden of proof would not interfere with informal procedures if it is decided that such procedures are to be retained.

\section{b. Use of Hearsay}

In the actual proof of facts, three basic problems run through almost all juvenile court litigation: the extent to which hearsay evidence should be utilized, the status of the protection against self-incrimination and the rules governing use of confessions, which have already been touched upon. ${ }^{123}$ Many of the evidentiary problems have been aggravated by a failure to analyze properly the role of juvenile court hearings. These hearings serve two separate and distinct functions: the court must first decide whether the minor actually committed the act for which he is charged, and then it must hear evidence to determine the proper form of treatment or disposition required. These will be referred to subsequently as the "fact-finding function" and the "dispositive function." Because most courts and legislatures fail to differentiate the two, one hearing usually serves to satisfy both. The result is that many facts relevant to the dispositive function, such as hearsay reports of social workers and psychiatrists and material concerning the juvenile's past history, which may very well prejudice the minor's defense against the factual claim that he committed a crime, are before the judge at the time he must make a decision whether it has been proved that the juvenile is actually guilty of the acts charged.

$121 \mathrm{Id}$. at 341-42, $38 \mathrm{S.E.2d}$ at 447. In a New Jersey case, In re Lewis, $11 \mathrm{~N}$.J. 217, 94 A.2d 328 (1953), concerning an adjudication for automobile homicide, the state conceded that proof beyond a reasonable doubt was required to sustain a judgment of delinquency. The court did not comment on this concession, except to cite State ex rel. Berry v. Superior Court, 139 Wash. 1, 245 Pac. 409 (1926), which held only a preponderance of evidence is required. In re Lewis, 11 N.J. 217, 221, 94 A.2d 328, 330 (1953).

122 Cad. Welfare \& Inst'ns Code $\$ 701$; see In re Corey, 230 Cal. App. 2d 813, 823, 41 Cal. Rptr. 379, 385 (1964). The constitutionality of the preponderance standard has been attacked on the ground that it is a violation of due process to commit a minor on less evidence than is required to convict an adult. The asserted noncriminal nature of juvenile court proceedings formed the basis for rejecting this argument. In re Johnson, 227 Cal. App. 2d 37, 38 Cal. Rptr. 405 (1964).

123 See pp. 1182-84 stupra. 
The status of hearsay evidence in the juvenile court is presently in doubt. On the one hand statements claiming that the rules of evidence are relaxed in the court are common, ${ }^{124}$ and apparently juvenile court judges actually permit large amounts of hearsay evidence to be presented at the hearing. ${ }^{12 \overline{5}}$ However, when an appellate court is faced with a case where hearsay has been admitted, the issue is rarely settled on the ground that technical rules of evidence do not apply. Rather, many courts carefully examine the record to determine whether the juvenile court's findings or judgment are supportable without the hearsay. ${ }^{126}$ The problem is further complicated by the statutes which prescribe informal procedures, ${ }^{127}$ as it is difficult to determine the extent to which they authorize relaxed rules of evidence.

Prior to a discussion of the case law there are several important observations to be made. The most basic is the attitude of the juvenile court judges toward the use of hearsay. It is possible that they believe that hearsay may be heard but that it is not, standing alone, a permissible basis for a factual finding. However, it is equally possible that these judges place hearsay on the same footing as direct evidence. It is not unlikely that a judge himself may be confused by permissive statutes and the general philosophy of the juvenile court, which does not acknowledge that juvenile hearings serve the same function as criminal trials. ${ }^{128}$ Thus the situation is distinguishable from a criminal trial heard by a judge without jury, where it is commonly said that the admission of hearsay is usually not grounds for reversal if other substantial evidence is present supporting the judgment, because in that situation an ordinary judge is aware of the rule against admission of hearsay and the right to cross examination. The regular criminal process, therefore, is willing to tolerate admission of some hearsay where a judge hears the case alone, because it is felt that he is attuned to the dangers of this type of evidence and the general proscription

124 See, e.g. Mont Appeal, 175 Pa. Super. 150, 156-57, 103 A.2d 460, 463 (1954); McLaughlin \& McGee, sipra note 111, at 229.

125 See, e.g., Handler, The Juvenile Court and the Adversary System: Problems of Function and Form, 1965 WIs. L. REv. 7, 16-17; Harvard Research Project 794-95:

The informality of juvenile court hearings frequently leads to the admission of hearsay and unsworn testimony. It is said that "close adherence to the strict rules of evidence might prevent the court from obtaining important facts as to the child's character and condition which could only be to the child's detriment." The assumption is that the judge will give normally inadmissible evidence only its proper weight. It is also declared in support of these evidentiary practices that the juvenile court is not a criminal court, that the importance of the hearsay rule has been overestimated, and that allowing an attorney to make "technical objections" would disrupt the desired informality of the proceedings.

126 See, e.g., In re Bently, 246 Wis. 69, 16 N.W.2d 390 (1944).

Some courts seem to say that the hearsay rule applies with full force in the juvenile court. See People v. Lewis, 260 N.Y. 171, 178, 183 N.E. 353, 355 (1932), cert. denied, 289 U.S. 709 (1933) ; People v. Fitzgerald, 244 N.Y. 307, 155 N.E. 584, 587 (1927) (dictum).

127 See pp. 1176, 1185 supra.

128 See note 125 supra. 
against its use, enabling him intellectually to disregard the hearsay when making a finding of fact. This may not be assumed in the juvenile court where the judge might be confused as to the permissible role of hearsay and could feel justified in giving hearsay the same status as direct evidence. Therefore, in the absence of a clear rule that hearsay evidence is not permitted in the juvenile court, it is no answer to say that its admission is no more dangerous than its admission in a criminal case heard without a jury. Further, the fact that criminal cases may be heard by a jury lessens the danger of hearsay. This protection is not available in juvenile courts. ${ }^{120}$ It seems clear, if it is deemed that the use of hearsay is harmful and should be greatly restricted, that current juvenile court procedures, in light of present uncertainty, are not sufficient to afford proper protection.

The clearest statement concerning the current state of the law of evidence in the juvenile courts is that most appellate courts will not uphold a judgment based solely on hearsay. ${ }^{130}$ Illustrating this principle is the case of In re Sippy, ${ }^{131}$ which concerned a judgment finding the minor to be habitually beyond the control of her parent and an order committing her to a school for an indefinite period. The only evidence presented consisted of two hearsay reports, the first made by an attorney reporting a conversation with the minor's physician, and the second a social worker's report containing statements made by the same physician, to the effect that the minor should "enroll" in a welfare school. The reversing court placed its decision on the grounds that the minor had been deprived of the right to cross examination and that it was error to base a finding totally on unsworn testimony. ${ }^{132}$

129 See notes 77 \& 78 supra and accompanying text.

130 Can it be that the legislature . . . intended to destroy the traditional and constitutional safeguards of a trial? Can it be intended that trials should be had without the benefit of testimony of witnesses given under the sanction of oath or affirmation? Can it be said that the legislature intended that the liberty of a child had less sanctity than that of an adult? Even if it did so intend, could that intention be sustained? We think not.

In re Mantell, 157 Neb. 900, 907, 62 N.W.2d 308, 311 (1954); see In re Hill, 78 Cal. App. 23, 247 'Pac. 591 (1926); cf. In re Davis, 83 A.2d 590, 594 (D.C. Munic. Ct. App. 1951).

13197 A.2d 455 (D.C. Munic. Ct. App. 1953).

132 See also In re Green, 123 Ind. App. 81, 108 N.E.2d 647 (1952), a notorious case which represents the nadir of reported juvenile court litigation. More than a total absence of direct evidence was involved in Green. A probation officer requested Green's father to appear with Green at the office of the probation department; neither father nor son was informed of the reasons behind the request. When they arrived they were taken into the chambers of the juvenile court judge, who requested that the minor leave the room. Without informing him why he was there or that charges had been filed against the juvenile, the judge told elder Green that he was going to send his son to the boy's school and "straighten him up." Green was granted no hearing, no witnesses were produced and no attorney or prosecutor was present. The judge based his determination wholly on hearsay testimony contained in a probation officer's report. The reversing court said:

The petition reveals a star chamber proceeding whereby a boy was torn from the custody of his parents and deprived of his liberty without a semblance of due process and by reason of a judgment that was not merely erroneous but absolutely void. We realize the Juvenile Court Act of 1945 permits courts to conduct hearings for the purpose of determining juvenile delinquency 
However, some courts have violated even this rather extreme line. Holmes' Appeal, ${ }^{133}$ for example, was a case in which a juvenile was deprived of his liberty even though no direct evidence was introduced. Holmes was adjudged a delinquent because he drove an auto without a license and was placed on probation. Five days later another petition was filed before the court charging the minor with participation in the armed robbery of a church. At the hearing apparently the only evidence supporting the latter charge was the testimony of a detective that one of the two men convicted of the same crime in criminal court had implicated the minor in his confession. The confession had been subsequently repudiated, including the statements implicating Holmes. In spite of this the minor was committed to the Pennsylvania Industrial School. In affirming the commitment, the state supreme court said "the fact that the testimony of the detective was technically 'hearsay' was . . . wholly unimportant," and the repudiation of the original confession was considered of little note because "the judge was not obliged to believe . . . [the] retraction." 134 A similar result obtained in another Pennsylvania case, In re Mont..$^{135}$ A detective read into evidence the juvenile's "apparently voluntary statement" of the facts concerning an alleged accidental shooting of which Mont was accused. Mont was then required to take the stand and corroborate his prior confession with self-incriminatory testimony. Additionally, there seems to have been a hearsay investigatory report before

in an informal manner and, to the end that the interests of the juvenile and of society generally shall be protected, the provisions of the act should be liberally construed without undue regard for the technicalities of the law that sometimes serve to protect those accused of crime. Nevertheless the act does not, nor could it within constitutional limitations, sanction the action of a court in finding a juvenile guilty of a wrong against the state in disregard of his rights to a hearing in which he is apprised of the charges against him and the evidence in support thereof and afforded an opportunity to defend himself.

Id. at $86-87,108$ N.E.2d at $649-50$.

$133379 \mathrm{~Pa} .599,109$ A.2d 523 (1954), cert. denied sub nom. In re Holmes, 348 U.S. 973 (1955).

134 Id. at 606, 109 A.2d at 526. It may be argued that Holmes should be considered a violation of probation case, and that the same standards for initially proving a criminal offense should not apply to a hearing where the issue before the court is merely a question of parole violation. As to the Holmes case there are two answers to this contention. The opinion of the Pennsylvania Supreme Court gives no indication that the case was viewed as a parole violation hearing; rather the court made broad statements concerning the applicability of evidentiary rules in the juvenile court. Further, the lower court in Holmes specifically held that even if the case is considered as a separate adjudication rather than a revocation of parole, none of the minor's rights were violated because the action was non-criminal. In re Holmes, 175 Pa. Super. 137, 143-44, 103 A.2d 454, 457 (1954).

Beyond these arguments, it is contended that in no case should a juvenile court be permitted to revoke parole without hearing adequate, legally reliable proof of the acts forming the basis for the parole revocation. Holmes provides an illustration why such a rule should be followed in the juvenile court. The juvenile was adjudged a delinquent for operating an auto without a license, a relatively minor offense, and placed on probation. The second offense, of which there was no direct proof, was the much more serious crime of armed robbery. While technically the court may have incarcerated Holmes for violation of his parole, it seems obvious that the court was willing to deprive him of his liberty only for the second offense. Yet under normal legal standards, no second offense was ever proved.

135175 Pa. Super. 150, 103 A.2d 460 (1954). 
the court. The judgment finding Mont to be a delinquent and committing him to reform school was affirmed on the alternative grounds that the hearsay was not necessary to support the judgment and that hearsay rules are not applicable generally to juvenile court proceedings. The latter alternative was based on the lower court opinion in Holmes, which confusingly states that the admission of hearsay is not reversible error if the record is "legally and factually adequate to sustain the findings and order of commitment." ${ }^{136}$ This statement seems to imply that a judgment may not be supported by hearsay alone, yet in Mont the major portion of the evidence adduced seems to have been just that, corroborated by selfincriminatory statements of the juvenile.

Beyond the relatively clear line of total absence of direct evidence, the entire area becomes murky. Most courts, unlike the Holmes court, are not willing to hold the hearsay rule inapplicable to juvenile court proceedings. However, sometimes hearsay has been introduced and the judgment affirmed without discussion of the applicability of hearsay rules. In re Garcia, ${ }^{137}$ a California case, is an illustration. The court rejected a claim of prejudice in the admission of a hearsay probation officer's report. This contention was disposed of quickly; the court held that there was not only a right to consider the report, but a duty to do so. It is possible to read a case like Garcia narrowly to hold that a probation report, which is probably required reading in the dispositive portion of the hearing, may be introduced in evidence before the judge sentences the minor. Thus the case may not stand for the proposition that hearsay evidence is generally admissible in juvenile courts, but that one type of hearsay report is permitted for sentencing purposes. In this light, the case is merely an example of the problems encountered because the fact-finding and dispositive functions are both satisfied in one hearing. Regardless of the way the case is considered, the fact remains that the judge is permitted to consider this type of evidence to the asserted prejudice of the minor prior to the time factual disputes are resolved.

It is much more frequent, however, to find courts acknowledging that the hearsay rule applies to some extent in the juvenile court and then struggling with the application. Some courts consider whether there was "sufficient" evidence aside from the hearsay to support the judgment.138 Thus Harry v. State ${ }^{139}$ sustained a finding of delinquency and a commitment even though the probation officer testified that the minor had threatened some boys with a knife "if they told certain things," because "there is ample proof to sustain the judgment of the court without the evidence

136 In re Holmes, 175 Pa. Super. 137, 146, 103 A.2d 454, 459 (1954).

137201 Cal. App. 2d 662, 20 Cal. Rptr. 313 (1962).

138 See, e.g., In re Brown, 201 S.W.2d 844 (Tex. Civ. App. 1947), where the court said that if there was sufficient evidence to support the judgment without the hearsay, unless the contrary is shown, it will be presumed that the court disregarded the hearsay in rendering judgment.

139246 Wis. 69,16 N.W.2d 390 (1944). 
in question . . ." 140 The unfortunate flaw in this type of reasoning is the danger that the juvenile court judge might have actually considered the hearsay in coming to a decision. In some cases the lack of findings of fact or opinion make it virtually impossible to determine what the juvenile court considered relevant, and the appellate court must assume that the hearsay was ignored, ${ }^{141}$ an assumption they seem willing to make in spite of the danger that the confused state of the law might mislead a juvenile court judge into believing that the use of hearsay in making factual findings is permitted. Another approach taken by some courts is to decide whether the hearsay admitted was prejudicial. ${ }^{142}$ This is preferable in that it does not force the courts to play the guessing game of whether the hearsay was considered. If it was admitted, and contained the danger of prejudice, grounds for reversal are present.

Hearsay evidence is generally not admissible in criminal trials for two reasons: it is thought to be basically unreliable and its use denies the defendant the right of cross examination. Unless a distinction can be found between a criminal trial and the fact-finding function of the juvenile court hearing-and none is apparent-the same reasons for rejecting hearsay testimony apply equally in the juvenile court when questions of fact are at issue. It is in the area of the dispositive function that hearsay evidence may properly play an important role. Reports which compile material gathered over a period of years concerning the minor's social, environmental and psychological problems are undoubtedly helpful to a judge deciding the proper form of disposition. Without this type of report the expense and time required to reconstruct all of the studies and examinations concerning the minor might well be prohibitive. Of course, in the best of all possible worlds it would be preferable to have before the court every psychologist, social worker, probation officer and police official who contributed to the social records of the minor, but if this is impossible, the use of social records and the testimony of probation officers and social workers currently working with the juvenile is a fair compromise. ${ }^{143}$ The problem should be resolved by the establishment of procedures which permit the fact-finding function to be satisfied at a hearing where the strict rules of evidence are observed and where only evidence relevant to the question of whether the minor committed the act for which he is charged is permitted, while providing for the satisfaction of the dispositive function in a more informal atmosphere where the rules of evidence are appropriately relaxed.

$140 I d$. at 81,16 N.W.2d at 395 .

141 See In re Brown, 201 S.W.2d 844 (Tex. Civ. App. 1947).

142 See Campbell v. Siegler, 10 N.J. Misc. 987, 162 Atl. 154 (1932); State v. Christensen, 179 Utah 361 , 227 P.2d 760 (1951), for examples of cases taking this approach and affirming judgments of delinquency where hearsay had been admitted. In Ballard v. State, 192 S.W.2d 329 (Tex. Civ. App. 1946), the court reversed the juvenile court on similar grounds.

143 Judges are permitted to use this type of hearsay report for sentencing purposes in regular criminal courts. See Williams v. New York, 337 U.S. 241 (1949). 
California and New York ${ }^{144}$ have attempted to solve these problems by dividing the hearing into two parts. ${ }^{145}$ Under the California code, after hearing evidence concerning the commission of the act, the court must make its factual findings, and if it is found that the minor committed the act, evidence may be heard on the issue of disposition. ${ }^{148}$ Apparently, the dispositional hearing may follow immediately after the fact-finding portion, or the court may continue proceedings after initial findings are made. ${ }^{147}$ To support a factual determination that the minor has committed a criminal act, a preponderance of the evidence legally admissible in criminal trials must be adduced. In other juvenile court cases a judgment against the defendant must be supported by a preponderance of the evidence legally admissible in civil cases. ${ }^{148}$

However, statutes like the California code, as enacted, leave major problems unsolved. While the division of the hearing could prove effective in removing from the factual hearing hearsay evidence necessary for a dispositional determination, the statute seems to permit the introduction of hearsay during the fact-finding hearing, ${ }^{149}$ and it certainly does not expressly prohibit it. If this is so, the same confusion concerning the use of second-hand evidence remains, with the possibility of some judges believing that it is to be given the same weight as direct evidence. Only the portion of the statute requiring a preponderance of evidence legally admissible in criminal trials to support a judgment points to an opposite conclusion, but this section may be read as codifying cases holding that the admission of hearsay is not grounds for reversal if sufficient other evidence is present.

144 (a) Only evidence that is competent, material and relevant may be admitted in an adjudicatory hearing.

(b) Any determination of an adjudicatory hearing that a respondent did an act or acts must be based on a preponderance of the evidence. For this purpose, an uncorroborated confession made out of court by a respondent is not sufficient.

N.Y. FANIIIY CT. ACT \$744.

(a) Only evidence that is material and relevant may be admitted during a dispositional hearing.

(b) An adjudication at the conclusion of a dispositional hearing must be based on a preponderance of the evidence.

N.Y. FAMIIY CT. ACT $\$ 745$.

145 Cal. Welfare \& Inst'ns Code $\$ \$ 701-02$.

146 Cal. Welfare \& Inst'Ns Code $\$ 702$.

$147 \mathrm{Ibid}$. After it is found that the minor has committed the offense charged, the court may continue the hearing for a period not to exceed ten days. This would seem to permit the trial judge to set aside time for himself or the lawyers to prepare for the dispositive hearing.

148 CAL. WeLFARE \& INST'NS CoDE $\$ 701$.

149 At the hearing, the court shall first consider only the question whether the minor is a person described by Sections 600,601 , or 602 , and for this purpose, any matter or information relevant and material to the circumstances or acts which are alleged to bring him within the jurisdiction of the juvenile court is admissible and may be received in evidence. . . .

CaI. WeLFare \& INST'NS CODE $\$ 701$. 
Another unanswered question under the California code is whether the finder of fact may read the social reports prior to the resolution of the factual dispute. The statute suggests that he may, because there is no requirement of a continuance between the first and second part of the hearing. ${ }^{150}$ Apart from the statute, In re Patterson ${ }^{151}$ may have settled the question in favor of allowing the trier of fact to read the reports before factual findings are made. In that case the minor complained that the judgment was not supported by sufficient evidence, and that the probation officer's report containing hearsay had been improperly admitted. The California Supreme Court rejected the hearsay contention, citing a case decided before the bifurcated hearing was instituted which permitted a probation officer's report to be admitted in evidence. ${ }^{152}$ It is not clear, however, at what point during the hearing in Patterson the report was introduced. If courts permit that type of hearsay to be admitted prior to the settlement of factual issues, much of the benefit of the bifurcated hearing is lost.

The problems encountered under an ambiguous law demonstrate that if hearsay is to be prohibited during the fact-finding hearing, the direction must be explicit. Even where the judge alone hears the case explicitness is necessary to clear up the confusion now present and to guarantee that hearsay erroneously or inadvertently admitted will not be considered when factual determinations are made. Of course, if juries come into wide use, the usual strict rules of evidence must be applied.

However, there are some who contend that the strict rules of evidence have no place in the juvenile courts and others who maintain that some rules are overly legalistic, concluding that only those which have been shown by human experience to protect the court against unreliable statements and distortions of fact should be retained in the juvenile court. ${ }^{153}$ The easy answer is that since juvenile courts hear criminal cases and deprive people of their liberty, they should offer the accused the same protection as do other courts performing the same function. However, one need not rest on this argument alone. It may very well be that the law of evidence is outmoded in some respects and reform by way of uniform codes would be a good thing. But the reform should reach the whole system. There should be little to distinguish the fact-finding function of the criminal and juvenile courts, and effective reform could reach both institutions simultaneously; but until this is done, it is doubtful that juvenile court judges and appellate judges should make piecemeal deci-

150 Section 702 merely grants the court discretion to continue the hearing.

15158 Cal. 2d 848, 27 Cal. Rptr. 10, 337 P.2d 74 (1962), cert. denied, 374 U.S. 838 (1963).

152 Id. at 853, 27 Cal. Rptr. at 13, 377 P.2d at 77, citing In re Halamuda, 85 Cal. App. 2d 219, 192 P.2d 781 (1948) (probation officer's report held admissible at hearing where child was removed from parents' custody). But see CAL. WELFARE \& INST'NS CODE $\$ 706$.

153 See Harvard Research Project 794-95. 
sions concerning which rules of evidence should be retained. This would seem to be a task requiring comprehensive legislative revision.

\section{c. The Privilege Against Self-Incrimination}

The second major evidentiary problem in juvenile courts is the use of self-incriminatory statements. Judging by the number of reported cases, it is not an issue often raised on appeal. This is not to say that it is unimportant since many juveniles, without the aid of counsel, admit at their hearings the charges brought against them, and most courts reaching the question have been willing to uphold judgments in cases where the minor has been forced to incriminate himself at the hearing.

The leading case holding that there is no constitutional right to protection against self-incrimination in the juvenile court is In re Santillanes, ${ }^{154}$ a 1943 New Mexico decision. The juvenile challenged the constitutionality of the act establishing juvenile courts on several grounds, including the failure to protect against self-incrimination. The state supreme court upheld the statute, simply accepting the dogma that juvenile court litigation is non-criminal. Some cases have held that not only is there no duty to warn the juvenile against incriminating himself but that the court may require him to answer incriminating questions even though he objects. ${ }^{155}$

In re Tahbel, ${ }^{156}$ decided by a California appellate court in 1920, is probably the earliest case granting juveniles protection against self-incrimination. After the minor was charged in a petition before the juvenile court with several crimes, including perjury, the petition was referred to a referee to hear testimony and report to the court. The minor, in the course of the referee's investigation, refused on advice of counsel to answer a question. At the hearing before the juvenile court on the referee's report, the judge instructed the minor to answer the question, and when he refused he was ordered committed to a juvenile institution until he complied. The appellate court granted a petition of habeas corpus, stating:

It would have been strange indeed if the legislature had sought to visit a minor with the loss of his natural parents' society, guidance, and government merely because, forsooth, he had the temerity to invoke the protection of a constitutional guarantee incorporated into the state's organic law for the very purpose of safeguarding his personal liberty against the methods that obtained when confessions were extorted by inquisitorial abuses. ${ }^{\mathbf{1 5 7}}$

15447 N.M. 140, 138 P.2d 503 (1943); see People v. Lewis, 260 N.Y. 171, 183 N.E. 353 (1932), cert. denied, 289 U.S. 709 (1933).

155 See Holmes' Appeal, 379 Pa. 599, 604, 109 A.2d 523, 525 (1954), cert. denied sub nom. In re Holmes, 348 U.S. 973 (1955); Mont Appeal, 175 Pa. Super. 150, 103 A.2d 460 (1954).

15646 Cal. App. 755, 189 Pac. 804 (1920).

157 Id. at 761, 189 Pac. at 807. 
Of course, Tahbel may be narrowly read to hold only that a juvenile may not be compelled under force of imprisonment to answer a self-incriminatory question. Subsequently, California appears to have adopted the position that there is no right against self-incrimination in the juvenile court. Twenty-seven years after Tahbel, in the case of In re Dargo, ${ }^{158}$ where a fourteen year old boy was committed to the Youth Authority for being implicated in a robbery netting eleven dollars, the court rejected a claim of self-incrimination because the minor was not being tried for a crime. The status of the protection against self-incrimination is unclear under the new California code as there seems to be no provision specifically granting that right.

The development in Texas is instructive. In 1944 the Texas Supreme Court held as a matter of statutory construction that a juvenile could not be forced to testify. ${ }^{159}$ In 1949 the state court of civil appeals acknowledged the right not to be forced to incriminate oneself in the juvenile court but held that the court was not required to inform the juvenile of his right. ${ }^{160}$ Because of the small number of juveniles represented by counsel before the court, ${ }^{161}$ the latter opinion virtually rendered the prior one nugatory. The most advanced state examined is New York, whose new statute contains a provision requiring that the juvenile be advised of his "right to remain silent" at the commencement of the hearing. ${ }^{162}$

As seen from the foregoing, the claim that the privilege against selfincrimination is not constitutionally required in the juvenile court proceeds from the oft repeated assertion that juvenile courts are not criminal courts and that they do not hear criminal cases. The fact still remains that children stand accused of criminal acts before the court, and, if found to have committed those acts, they stand in jeopardy of being deprived of their liberty. Even if we do not proceed on the constitutional level, but consider the question of what the juvenile courts should do rather than what they are required to do, minors should not be required to incriminate themselves. The usual rationale for the privilege is that ours is an accusatorial rather than an inquisitorial system and that by not requiring a person to testify against himself the worst aspect of the inquisitorial system-placing the accused on the witness stand and dragging a confession out of him-is eliminated. The juvenile court is one area where this may be a real danger since the accused are always young and in many instances inexperienced. ${ }^{103}$ It is absurd to protect adults from this danger but to let juveniles take their chances. Furthermore, it is possible that a confession drawn from a juvenile while being intimidated

15881 Cal. App. 2d 205, 183 P.2d 282 (1947).

159 Dendy v. Wilson, 142 Tex. 450, 179 S.W.2d 269 (1944).

160 Williams v. State, 219 S.W.2d 509 (Tex. Civ. App. 1949).

161 See note 83 supra and accompanying text.

162 N.Y. FAumy CT. Acr \$ 741.

163 See note 157 supra and accompanying text. 
on the witness stand will be untrue. It seems clear that informing the juvenile of his privilege is necessary to make it effective.

\section{d. Transcripts of the Evidence}

Related to the policing of evidence admitted in juvenile court hearings is the ability of the minor to procure a transcript of the hearings. It is common to find appellate courts indulging, without a transcript, in presumptions or assumptions concerning the conduct of the hearing and the basis for the lower court's judgment. ${ }^{164}$ Obviously dismayed by this state of affairs, the Oklahoma Supreme Court held that the failure of the juvenile court to require a stenographic record was violative of due process. ${ }^{165}$ Under the California code, an official reporter must take the record at any hearing conducted by a judge of the juvenile court, and if the judge or the parties so request, must transcribe it. ${ }^{166}$ The costs of transcribing the record are borne by the person requesting the transcription unless the court in its discretion otherwise directs. ${ }^{107}$ Not all states, however, go this far. Under the rules of the New Jersey courts, stenographers are required only in cases where the juvenile is charged with homicide. ${ }^{168}$ In all other cases, if the minor desires a record, he must hire a reporter and at the request of the court is required to file a copy of the transcript at his own expense. ${ }^{169}$

A statute that requires less than a reporter at all juvenile court hearings at the cost of the state, together with a provision for the costs of transcription in cases involving indigents, is inadequate in the context of the juvenile court system. Without a record the appeal process is reduced to a guessing game.

164 See Irr re Garcia, 201 Cal. App. 2d 662, 20 Cal. Rptr. 313 (1962) ; State v. Smith, 32 N.J. 501, 515-16, 161 A.2d 520, 527-28 (1960), cert. denied, 364 U.S. 939 (1961). A California court has refused to indulge in such presumptions. In re Alexander, 152 Cal. App. 2d 458, 313 P.2d 182 (1957).

165 In civil proceedings affecting property rights of a child, every right is safeguarded lest the child become the victim of oppression and skullduggery. Records of such proceedings are meticulously preserved. Should we observe any less concern of a child's life and liberty than we do for his property? Should he be subject to what a record of the hearing might disclose was in the nature of a Star Chamber proceeding? The answer obviously should be, no. Yet in cases of this kind, the failure of the statute to spell out the proceedings permits less caution than it provides in civil cases on the matter of recording the proceedings. In Juvenile Courts the proceedings may be conducted in such an informal manner with no transcript required to be made that what was done becomes a matter of mere conjecture, surmise, and guess. Without a record of the proceedings, upon what basis can a rational adjudication by review of the petitioner's rights be predicated? Not to require the making of a formal record in such cases subjects the child to an exercise of arbitrary will, whim, or caprice of the judge, with no record upon which to attack it. We cannot reconcile such procedure with the orderly processes associated with the law.

In re Smith, 326 P.2d 835, 839-40 (Okl. Crim. Ct. App. 1958).

166 CAL. WeLFARE \& INST'NS CODE $\$ 677$.

167 Ibid.

168 N.J. RULES 6:9-1(b).

169 N.J. RULES 6:2-10. 


\section{e. Waiver of Jurisdiction}

In Kent v. United States, ${ }^{170}$ the United States Supreme Court faced the problems raised by a procedure virtually unique to the juvenile court system, the power of the juvenile court to relinquish its jurisdiction under certain circumstances to permit the state to prosecute the minor in a regular criminal court. This procedure, usually called relinquishment of jurisdiction or waiver of jurisdiction, will be referred to simply as waiver.

The purpose or purposes of permitting waiver are not clear. Various justifications have been articulated, but apparently no jurisdiction has carefully spelled out the underlying policy. The result has been a great deal of confusion as to what tests should be applied by a court considering waiving jurisdiction. The waiver statutes add little to the understanding of the process, other than at what age a minor is vulnerable to ordinary criminal prosecution. For example, the District of Columbia Code permits the court "after full investigation" to waive jurisdiction of juveniles aged sixteen and seventeen who are charged with offenses considered felonies under ordinary criminal law and of juveniles of any age who are accused of crimes punishable by death or life imprisonment.171 The full investigation standard is left unexplained, and the statute offers no further guidance. The New Jersey statute permits waivers

if it shall appear to the satisfaction of the juvenile and domestic relations court that a case of juvenile delinquency . . . committed by a juvenile of the age of 16 or 17 years, should not be dealt with by the court, either because of the fact the person is an habitual offender, or has been charged with an offense of a heinous nature, under circumstances which may require the imposition of a sentence rather than the disposition permitted by . . . [the Juvenile Court Act] for the welfare of society . . ..172

Under Alabama law jurisdiction of a child over the age of fourteen may be waived if it is found that he "cannot be made to lead a correct life and cannot be properly disciplined" under the provisions of the juvenile court law. ${ }^{173}$

17086 Sup. Ct. 1045 (1966).

171 D.C. CODE ANN. §11-1553 (Supp. V, 1966).

172 N.J. Rev. Stat. \&2A:4-15 (1952); see N.J. Rules 6:9-7. Under the New Jersey statute a sixteen or seventeen year old juvenile can cause his own waiver by demanding a trial by jury. When such a demand is made to the court, it must refer the case to the prosecutor for normal criminal adjudication. N.J. REv. STAT. §2A:4-15 (1952).

${ }_{173}$ ALA. Code tit. 13, $\$ 364$ (1958). Alabama, which provides the juvenile court with exclusive jurisdiction only over minors under sixteen, also provides for the reverse of waiver. Instead of the juvenile court making the first determination whether a sixteen or seventeen year old offender should be prosecuted criminally, the criminal court is given initial jurisdiction over such offenders and is given the power to transfer them to a juvenile court if it deems "it to be in the interest of justice and of the public welfare. ALA. CoDE tit. $13, \S 363$ (1958); see Davis v. State, 259 Ala. 212, 66 So. $2 d 714$ (1953). Of course, fourteen and fifteen year old minors may be transferred from the juvenile court. 
California law on this subject is particularly confusing; one section of the state code permits waiver if the court finds that the minor "is not a fit and proper subject to be dealt with" in the juvenile courts, mentioning no age limits or other special requirements, ${ }^{174}$ while a second section states:

At any time during a hearing upon a petition alleging that a minor is, by reason of violation of any criminal statute or ordinance, a person described in Section 602, when substantial evidence has been adduced to support a finding that the offense alleged is punishable as a felony under the general law and that the minor was 16 years of age or older at the time of the alleged commission of such offense, or that the offense alleged is punishable as a misdemeanor under the general law and that the minor was 18 years of age or older at the time of the alleged commission of such offense, and that the minor would not be amenable to the care, treatment and training program available through the facilities of the juvenile court, . . . the court may make a finding ... that the minor is not a fit and proper subject to be dealt with under this chapter, and the court shall direct the district attorney . . . to prosecute the person under the applicable criminal statute . . ..$^{175}$

Why and how these two sections coexist in the same statute is unexplained; it has, however, been held that the latter is not the exclusive vehicle for waiver. Thus, in Knight v. Superior Court ${ }^{176}$ the juvenile court was permitted to waive jurisdiction of a child under sixteen utilizing the predecessor of the first section. ${ }^{177}$

A questionnaire circulated among fifty juvenile courts revealed that five factors commonly are taken into account in a decision to waive jurisdiction: (1) issues of contestable fact indicate that the hearing in the juvenile court will be prolonged; (2) the offense, occurring after cor-

174 CaL. Welfare \& Inst'ns CODE $§ 606$.

When a petition has been filed in a juvenile court, the minor who is the subject of the petition shall not thereafter be subject to criminal prosecution based on the facts giving rise to the petition unless the juvenile court finds that the minor is not a fit and proper subject to be dealt with under this chapter and orders that criminal proceedings be resumed or instituted against him.

175 Cal. Welfare \& INST'NS CODE $\$ 707$.

176102 Cal. App. $2 d$ 211, 227 P.2d 62 (1951).

177 One court has interpreted the provisions corresponding to $\$ \$ 606$ and 707 under prior law. It was held that in cases where the minor was brought before the juvenile court initially by certification from a criminal court, rather than by petition filed in the juvenile court, the special requirements of the prior $\$ 707$ need not be satisfied. People v. Yeager, 55 Cal. 2d 374, 359 P.2d 261, 10 Cal. Rptr. 829 (1961). This is an unsatisfactory explanation, for no other section of the code distinguishes cases on the basis of origin, and the sections give no indication that such a distinction should be made. It is strange that the drafters did not clarify this ambiguity when the new code was enacted. 
rectional treatment for a previous transgression, is serious; (3) the juvenile's case is "hopeless"; (4) the juvenile needs to be punished for his attitude; (5) the advantages in resources for treatment and public safety lie with the criminal court rather than the juvenile court. ${ }^{178}$ The juvenile court of the District of Columbia, apparently in an attempt to beef up a meager statute, published a policy memorandum listing the considerations germane to the issue of waiver. Included in the list were: the seriousness of the alleged offense and the need for community protection; whether the offense was committed in a violent or aggressive manner; the prosecutive merit of the complaint judged by the strength of the evidence after consultation with the United States attorney; and the sophistication of the juvenile, his past record and the chances for rehabilitation. ${ }^{179}$ The memorandum containing these standards has been withdrawn, apparently in response to a barrage of criticism, and currently the District of Columbia court is operating under the unaugmented "full investigation" standard. ${ }^{180}$ However, except for these two sources, information concerning factors motivating judges to relinquish jurisdiction is scarce.

Statistically, it does not appear that the number of waivers is large;181 it must be kept in mind, however, that no thoroughgoing study has been made, and the available statistics are rather sketchy. It also appears that some courts are freer in their attitude toward waiver than others ${ }^{\mathbf{1 8 2}}$ consequently, while absolute figures may not be large, in some jurisdictions relinquishment of jurisdiction is a problem of substantial proportions. Of even greater importance is the fact that almost all waiver cases involve

178 Advisory Council of Judges, National Council on Crime and Delinquency, Transfer of Cases Between Juvenile and Criminal Court: $A$ Policy Statement, 8 CRIME \& Delinguency 3, 5 (1962). These responses are criticized. Id. at 5-7.

179 Kent v. United States, 86 Sup. Ct. 1045, 1060 (1966). In Green v. United States, 308 F.2d 303 (D.C. Cir. 1962), the court, citing the policy memorandum, said: "The Juvenile Courts waiver of jurisdiction, whatever else it is, is also a judicial finding of probable cause to believe the accused guilty." Id. at 304.

180 United States v. Caviness, 239 F. Supp. 545, 550-51 (D.D.C. 1965). In the Caviness case, where the propriety of the waiver was in issue, the Executive Director of the Social Service testified as to standards applied in a decision to waive, and when he was questioned about standards after the policy memorandum was withdrawn, his response was that the judge of the juvenile court "may or may not have considered "the basic things that were in the published criteria." "Id. at 550 .

United States v. Madsen, 148 F. Supp. 625 (D. Alaska 1957), provides an example of how even the minimal standard of full investigation can be emasculated. The court held that an investigation of the circumstances of the homicide conducted by the U.S. Commissioner, who also acted as coroner and as justice of the peace, satisfied the full investgation requirement of the statute, even though no social investigation of the minor was conducted prior to waiver.

181 See Advisory Council of Judges, supra note 178, at 10; Statistical Comparison of Children's Courts Serving the Nation's Twelve Largest Cities, 13 JuvennE $\mathrm{C}_{\mathrm{T}}$. JUDGES J. 14, 14-15 (1962).

182 It is reported in Harrison v. United States, No. 17991, D.C. Cir., Dec. 7, 1965 , that in 1962, 235 out of 2600 cases referred to the juvenile court resulted in waivers. However, it is noted that the total number of referrals may be overstated.

See Advisory Council of Judges, supra note 178, at 10. 
minors who have committed serious offenses or who have been before the juvenile court previously. ${ }^{183}$ This is the group probably most in need of rehabilitative treatment and most likely to have anti-social tendencies which would be reinforced by contact with adult criminal offenders, a possible result of criminal conviction.

Because the decision to waive is extremely important, potentially affecting the entire future of a juvenile, one might expect that procedures would be established carefully to safeguard his interests. This is not always the case. The District of Columbia code, for example, requires no procedural protections, and only by virtue of a series of court decisions are minimum protections attached to the waiver procedure. ${ }^{184}$ During the period when not even a hearing was required the D.C. Circuit had ruled that a minor was entitled to counsel while the court was deliberating the question of waiver, ${ }^{185}$ and not until the current term did the Supreme Court in Kent decide that a hearing was required or that the juvenile court need file an opinion stating the reasons for relinquishing jurisdiction. ${ }^{186}$ Prior to the Supreme Court's ruling it was virtually impossible to ascertain the basis for waiver. However, the Supreme Court did not solve the problem raised by the lack of standards in the waiver statute and left untouched the narrow scope of review enunciated by the court of appeals, which allows reversal of waiver only when the juvenile court acted arbitrarily or capriciously. ${ }^{187}$ It would seem virtually impossible to reverse under such standards if the juvenile court followed proper procedure, because without a standard to judge by, how may it ever be said that a court acted arbitrarily? ${ }^{188}$ An illustration is the court of appeals' opinion in Kent, where it was held that the waiver was not

183 See Edwards v. United States, 330 F.2d 849 (D.C. Cir. 1964) (robbery by force and violence); United States v. Stevenson, $170 \mathrm{~F}$. Supp. 315 (D.D.C. 1959) (assault of a police officer); Duck v. State, 176 So. 2d 497 (Ala. Sup. Ct. 1965) (murder); In re Brekke, 233 Cal. App. 2d 196, 43 Cal. Rptr. 553 (1965) (murder -repeated offender) ; People v. Machado, 150 Cal. App. 2d 190, 309 P.2d 903 (1957) (felony-murder); People v. Renteria, 60 Cal. App. 2d 463, 141 P.2d 37 (1943) (automobile theft-repeated offender); State v. Loray, 46 N.J. 179, 215 A.2d 539 (1965) (murder); State v. Smith, 32 N.J. 501, 161 A.2d 520 (1960), cert. denied, 364 U.S. 939 (1961) (felony-murder).

184 Kent v. United States, 86 Sup. Ct. 1045 (1966) (hearing required before waiver; juvenile court must state reasons for waiver); Black v. United States, 355 F.2d 104 (D.C. Cir. 1965) (right to counsel during waiver deliberations granted); Watkins v. United States, 343 F.2d 278 (D.C. Cir. 1964) (minor's attorney may inspect social records).

185 Black v. United States, supra note 184.

186 Kent v. United States, 86 Sup. Ct. 1045 (1966).

187 Kent v. United States, 343 F.2d 247, 252 (D.C. Cir. 1965).

Prior to the Supreme Court's decision in Kent, it had been held that a waiver certificate stating that a full investigation was made is presumed valid. United States $\mathrm{v}$. Green, 200 F. Supp. 687, 688 (D.D.C. 1961), rev'd on other grounds, 308 F.2d 303 (D.C. Cir. 1962); see Wilhite v. United States, 281 F.2d 642, 643 (D.C. Cir. 1960). The present status of this presumption is unclear.

188 In Briggs v. United States, 226 F.2d 350 (D.C. Cir. 1955), an attack on the constitutionality of the waiver statute (asserted voidness for lack of standards) was rejected. 
arbitrary because "the essence of the juvenile court system is subjective judgment-the skill and experience of the specialist judge brought to bear upon young people in trouble." 189 Beyond this, after years of experience under the D.C. code it is still unclear whether an appellate court has the power to remand a case back to the juvenile court even if it finds the waiver to have been arbitrary and capricious. ${ }^{190}$ If there is no power, the adult court has only one alternative if it feels that the juvenile would best be dealt with under juvenile court law; the D.C. code provides a safety valve procedure whereby the district court may convene itself as a juvenile court. ${ }^{191}$ Not only is this procedure rarely used, ${ }^{192}$ but it forces the district court to act as a specialized tribunal in an area where it has no special expertise when an expert court is available. A far more rational solution would be to permit remand to the juvenile court after waiver.

In other jurisdictions the procedures leading to waiver vary. Alabama, a state which is fairly backward in providing juveniles procedural protections, ${ }^{193}$ seems to afford a hearing before waiver, and evidence concerning the minor's guilt is not sufficient to sustain a waiver order. ${ }^{194}$ However, no right to counsel is provided. ${ }^{195}$ A series of recent decisions

189 Kent v. United States, 343 F.2d 247, 253 (D.C. Cir. 1965).

190 See United States v. Caviness, 239 F. Supp. 545, 546 (D.D.C. 1965), interpreting Pee v. United States, 274 F.2d 556 (D.C. Cir. 1959).

191 D.C. CoDE ANN. $\$ 11-1553$ (Supp. V, 1966). This procedure was utilized in United States v. Anonymous, 176 F. Supp. 325 (D.D.C. 1959). See United States v. Caviness, 239 F. Supp. 545, 552 (D.D.C. 1965).

192 A colloquy by defense counsel and a district court judge reported in Franklin v. United States, 330 F.2d 205 (D.C. Cir. 1964), concerning the question of whether the district court should convene itself as a juvenile court, may indicate attitudes of judges to this procedure:

Mr. Harrison [defense counsel] : Under the Pee case, Your Honor, . . . this court in its discretion has the right to try Price as a juvenile if you so desire. At this time I request that you do so.

The Court: I decline the request because that is a power that I have not exercised because $I$ think it is perfectly foolish for the Juvenile Court to waive jurisdiction on the theory that a person should be tried in the District Court and then the District Court gives juvenile procedures. No, I am not going to reverse or set aside the discretion of the Juvenile Judge, which, in effect, I would be doing. In any event, entirely aside from that, when a person is charged with robbery and rape he should be tried as an adult.

Id. at 209-10 n.4. In reversing, the court of appeals said:

In making this determination, the court must consider the individual case before it and not refuse to exercise its discretion because of a preconceived notion that the statute which gives it the right so to do is "foolish" or that the statutory discretion should never be exercised affirmatively "when a person is charged with robbery and rape."

Id. at 210 .

193 See generally McLaughlin \& McGee, Juvenile Contr Procedure, 17 ALA. L. REv. 226 (1965).

194 See Duck v. State, 176 So. 2d 497 (Ala. Sup. Ct. 1965) ; Stapler v. State, 273 Ala. 358, 141 So. 2d 181 (1962) (Evidence tending to show that the juvenile committed the offense may not, standing alone, support a waiver order).

185 See McLaughlin \& McGee, supra note 193, at 228. 
in New Jersey have held that a hearing is required before waiver, ${ }^{106}$ and in cases involving homicides counsel must be appointed to represent the juvenile at a waiver hearing. ${ }^{197}$ It remains to be seen whether the right to counsel will be granted for all such hearings.

An examination of the law concerning waivers does not satisfactorily explain the purpose behind permitting such relinquishment of jurisdiction. Several bases are suggested; that if the crime is serious enough the juvenile court ought not to hear the case; if the juvenile is arrogant he should be taught a lesson; or if he is a repeated offender his case is probably hopeless, and he is better "punished" than "treated." However, these arguments may all be boilerplate, masking the real concern behind waiver. Under almost all juvenile court statutes incarceration is permitted only until age twenty-one. ${ }^{198}$ In cases involving sixteen or seventeen year old delinquents who are repeated offenders or who have committed serious offenses such as murder or assault with a deadly weapon, the fear of unleashing these persons on society in three or four years may be real. Protection to society may reasonably be said to require that these minors be restrained of their liberty at least until the psychologists and psychiatrists who will work with them feel they are sufficiently rehabilitated that they are no longer a public menace. Commonly, the permissible term of imprisonment for serious offenses is long; therefore, conviction in an ordinary criminal court will satisfy the need for public protection, but at the expense of making unavailable the rehabilitative facilities of the juvenile institutions and permitting young offenders to mingle with hardened criminals in an ordinary prison. ${ }^{199}$ The juvenile may leave a greater menace than when he arrived. A second consideration which may underlie waiver is the desire to protect the mass of juvenile offenders who are incarcerated from the hardened delinquent. By criminally prosecuting the worst juveniles they will be removed from juvenile institutions where they may exert a harmful influence. Related to this concern is the problem presented by

196 State v. Van Buren, 29 N.J. 548, 150 A.2d 649 (1959):

The decision to retain or relinquish jurisdiction is obviously meaningful to an alleged offender as well as to society, and hence, whatever may be thought of the demands of due process in this situation, fairness to both suggests that there be a hearing to aid the court in reaching a decision.

$I d$. at $555-56,150$ A.2d at 653 .

197 State v. Tuddles, 38 N.J. 565, 186 A.2d 284 (1965) ; see State v. Loray, 215 A.2d 539 (N.J. Sup. Ct. 1965).

198 See, e.g., Kent v. United States, 343 F.2d 247, 262 (D.C. Cir. 1965); Huff v. O'Bryant, 121 F.2d 890 (D.C. Cir. 1941); Kautter v. Reid, 183 F. Supp. 352 (D.D.C. 1960); AlA. CoDe tit. 13, §354 (1958); D.C. CoDE ANN. \$11-1551(b) (Supp. V, 1966).

Under California law the jurisdiction of the juvenile court over the minor may continue until he reaches twenty-one. But if a minor is nineteen or older at the time of adjudication, the court may retain jurisdiction of him for two years from the date of adjudication. CAL. WELFARE \& INST'NS CODE $\$ 607$. The California court may hear cases concerning minors up to age twenty-one. See People v. Cavanaugh, 234 Cal. App. 2d 316, 44 Cal. Rptr. 422 (1965).

109 However, some jurisdictions, such as the District of Columbia, California and New York, have special provisions for sentencing youthful offenders convicted of offenses in the criminal courts. 
limited resources. Since there is presently a strain on juvenile court facilities, a judge faced with a particularly difficult case might feel that a large expenditure of time is not justified because of the low probability of successful rehabilitation.

To deal with juveniles committing homicides, New Jersey has devised a system which does not include waiver. In such cases a hearing similar to a criminal trial is utilized by affording the minor the right to counsel and by bringing in a member of the prosecuting attorney's staff to present the state's case. ${ }^{200}$ Presumably, normal evidentiary rules apply. If the juvenile is found guilty, the judge may sentence him for a period up to the maximum term provided under the general law for the crime, ${ }^{201}$ but the juvenile has a right to be freed whenever he is sufficiently rehabilitated to assume a normal role in society. ${ }^{202}$ Apparently, juveniles convicted and sentenced in this manner are placed in juvenile institutions, or, if placed in penal institutions, they are somewhat segregated. Obviously it is felt that by providing a hearing approximating a criminal trial no constitutional problems are raised by the extended sentencing procedures. ${ }^{203}$ If these procedures were expanded to encompass lesser offenses and all constitutional questions were satisfied by granting a full "constitutional" trial along with regular pre-trial protections, the need for waiver could be totally eliminated. ${ }^{204}$ Of course, an enlarged and more intelligent use of juvenile incarceratory facilities would be required.

\section{f. Protection Against Double Jeopardy}

The least litigated issue in the area of procedural protections and constitutional rights in the juvenile courts is protection against double jeopardy. While there is some authority going each way, the great majority of cases hold there is no protection, and most of the contrary authority is rather recent. People $v$. Silverstein ${ }^{205}$ is the case most frequently cited for the proposition that there is no protection against double jeopardy in the juvenile court. In that case the minor was judged a ward of the court on a charge of burglary and was confined to an institution for fifteen months. Upon his release he was certified back to the juvenile court by the Youth Authority, and the court certified his case

200 N.J. $6: 9-1$ (b).

201 See In re Steenback, 34 N.J. 89, 186 A.2d 397 (1961) ; In re Smigelski, 30 N.J. 513,154 A.2d 1 (1959); Johnson v. State, 18 N.J. 422,114 A.2d 1 (1955), cert. denied, 350 U.S. 942 (1956); N.J. REv. STAT. 2A :4-37 (Supp. 1965).

202 See In re Steenback, supra note 201, at 101-02, 167 A.2d at 403; cf. State v. Wingler, 25 N.J. 161, 135 A.2d 468 (1957).

203 Compare In re Smigelski's Petition, 185 F. Supp. 283 (D.N.J. 1960), with Application of Johnson, 178 F. Supp. 155 (D.N.J. 1957).

204 See Sargent \& Gordon, Waiver of Jurisdiction: An Evaluation of the Process in the Juvenile Court, 9 CRIME \& DELINQUENCX 121 (1963), calling for the abolition of waiver.

205121 Cal. App. 2d 140, 262 P.2d 656 (1953). See In re McDonald, 153 A.2d 651 (D.C. Munic. Ct. App. 1959); In re Santillanes, 47 N.M. 140, 138 P.2d 503 (1943). 
to the superior court for further proceedings. The juvenile was then tried for the same crime in the superior court, an ordinary criminal tribunal, found guilty and sentenced to a term in the state prison. The appeal taken was denied, the court holding the protection against double jeopardy inapplicable because the juvenile court proceedings were non-criminal.

There is a tendency in some state legislatures and rule making bodies totally to ignore the protection against double jeopardy. Silverstein relied on provisions of the California code permitting Youth Authority officials to return to the juvenile court delinquents who have proved troublesome in juvenile institutions and authorizing the juvenile court to certify these delinquents to the criminal courts. ${ }^{206}$ Under the New Jersey rules of court, the juvenile court may refer a minor to criminal courts any time before "final disposition" regardless of how far the hearing may have progressed." ${ }^{207}$ The rule continues: "The hearing before the court shall then be construed as preliminary in nature to determine whether the complaint should be referred to the prosecutor or retained by the court." 208 The Alabama code permits waiver "after thorough investigation or exercise of [the juvenile court's] disciplinary measures." 209

United States v. Dickerson, ${ }^{210}$ decided in 1958 by the District Court for the District of Columbia, is possibly the first clear-cut holding that protection against double jeopardy obtains in the juvenile court. After Dickerson was arrested on a charge of robbery he was brought before a juvenile court where he admitted the facts stated in the petition, such an admission being tantamount to a guilty plea. The case was continued for social study and recommendation for disposition. In the meantime, the boy was placed in the District of Columbia Receiving Home. Two weeks later the court waived its jurisdiction, and the grand jury returned an indictment charging Dickerson with robbery. The district court then granted a motion to dismiss the indictment on the ground of double jeopardy. The opinion eschewed the criminal-non-criminal distinction, holding that the right not to be put twice in jeopardy "is present in any proceeding and in any tribunal if the liberty of the individual is involved." ${ }^{111}$ The court then found that jeopardy attached when the minor acknowledged his guilt before the court. The court of appeals reversed, ${ }^{212}$ but not on the ground that jeopardy can never attach in a juvenile court; rather it found that jeopardy did not attach under the circumstances because the proceedings never passed the preliminary hearing stage.

A 1963 Texas litigation resulted in an unreversed holding that in effect jeopardy may attach in a juvenile court. ${ }^{213}$ The circumstances are

208 See Cal. Wezfare \& Inst'ns CODE §707.

207 N.J. RuLES 6:9-7.

208 Ibid.

209 ATA. CODE tit. 13, \& 364 (1958).

210168 F. Supp. 899 (D.D.C. 1958).

211 Id. at 901 .

212 United States v. Dickerson, 271 F.2d 487 (D.C. Cir. 1959).

213 Garza v. State, 369 S.W.2d 36 (Tex. Ct. Crim. App. 1963). 
particularly shocking. The minor, accused of committing a homicide, was at the time of the offense only five or six months short of seventeen, the upper age limit of juvenile court jurisdiction in Texas. The district attorney attempted to obtain a nonsuit in the juvenile court before any formal proceedings began because he desired to prosecute in a regular court when the minor reached seventeen. This motion was overruled, and when the case came to trial the district attorney filed a motion to dismiss for want of jurisdiction, which was overruled, followed by a motion for continuance, also overruled. The district attorney then proceeded to plead "under fear of contempt of court and attending penalties," stating: "We feel that by continuing to proceed in this juvenile hearing that we would thereafter be precluded to try this juvenile as an adult within 5 or 6 months from now." 214 After a hearing in the juvenile court at which the minor was found to have committed the act, he was committed to a state school for boys where he remained until he reached seventeen. At that time he was indicted for the same crime in the regular criminal court, where he was convicted and sentenced to seven years in jail. The conviction was reversed by the criminal court of appeals as a violation of the principles of fundamental fairness and a deprivation of due process under the fourteenth amendment.

It is indefensible that a juvenile, as in Silverstein, could be deprived of his liberty for well over a year following one adjudication, and then be retried for the same crime and sent to another institution for a second term. It is indeed paradoxical that our system would not permit this to happen to an adult.

\section{General Criticisms}

A great deal may be written about juvenile court procedures affording less protection to the young criminal offender than the general criminal system affords his elder counterpart. Up to this point, however, this Comment has not directly attacked the validity of the assumptions which underlie the whole juvenile court system. In the preceding pages it was suggested that the price the juvenile is forced to pay outweighs the claimed benefits supporting informality. Now the arguments supporting informality and the abolition of procedural protections must be examined.

Are juvenile courts non-criminal? We know that they have obvious similarities to criminal courts; persons are tried before them for anti-social acts commonly referred to as crimes, and if those persons are found to have committed the acts, the court has the power to deprive them of their liberty for a period of time. But what of the argument that criminal courts punish while juvenile courts treat, and criminal convictions stigmatize while juvenile court litigation does not? 
Criticism has been heaped upon the juvenile institutions. The following are examples of the commentary:

The appearance and meaning of a reformatory to a child may not correspond with the judicial label of "protection." Most reform schools are no more than junior prisons, with the same restraint of action as is found in a large measure of adult penal institutions, both state and federal. Moreover, it is well known that when the child returns to society after a period of "treatment" in a reformatory, his opportunities are definitely jeopardized. ${ }^{215}$

There are things going on, methods of discipline used in the state training schools of this country, that would cause the warden of Alcatraz to lose his job if he used them on his prisoners. There are practices that are a daily occurrence in some of our state training schools that are not permitted in the prisons or penitentiaries of some states. There are many states in which the discipline is more humane, more reasonable, in the prison than it is in the state training school. ${ }^{216}$

The most blatant discrepancy between theory and practice occurs in the character of the custodial or treatment institutions. It is charged that most reform schools are little more than prisons, dominated by fear and repression. Where corporal and other degrading punishments are used, the schools are considerably worse than the average maximum security prisons. At least for some of these adolescents confinement in what amounts to a prison will be the second such experience in the course of the same case since it is reported that many adolescents are detained in jails awaiting trial. ${ }^{217}$

If the above statements relate an accurate picture of the state of juvenile institutions, and there is little published material to refute them, then to say that juvenile court litigation will not result in punishment similar in nature to that used against adult criminals is mere self-deception.

Is it true that the stigma of criminality does not attach in juvenile court litigation? On this subject a California court has said:

While the juvenile court law provides that adjudication of a minor to be a ward of the court shall not be deemed to be a conviction of a crime, nevertheless, for all practical purposes, this is

215 Rappeport, Determination of Delinquency in the Juvenile Court: A Suggested Approach, 1958 WASH. U.L.Q. 123, 126-27.

216 Id. at 126 n.8, citing MacCormick, The Essentials of a Training School Program, in National Councm of Juvenile Court Judges, Pittsburgh Conference 50 (1950).

217 Handler, The Juvenile Court and the Adversary System: Problems of Function and Form, 1965 WIS. L. REv. 7, 12-13. 
a legal fiction, presenting a challenge to credulity and doing violence to reason. The courts cannot and will not shut their eyes and ears to everyday contemporary happenings. ${ }^{218}$

As noted before, statutes provide that official stigmas resulting from criminal conviction will not be placed on the juvenile offender. ${ }^{219} \mathrm{He}$ will not, for example, be barred from civil service positions. ${ }^{220}$ Juvenile courts also attempt to keep court records confidential and private hearings may help to lessen publicity. But public stigmas are not the only ones that attach to criminal litigation; subtle, and not so subtle, methods have been devised to circumvent the confidentiality of juvenile court litigation.

Most evidence points to the fact that juvenile offenders, especially those who have served time in a reformatory, experience difficulties in securing employment, economic advancement, admission to schools and colleges, professional opportunities and even opportunities in the armed services. ${ }^{221}$ Many employers have devised methods of obtaining information concerning a prospective employee's juvenile record. They may coerce the job applicant into signing a request to the juvenile court for release of his record by making the signing of such a release a prerequisite for further consideration. ${ }^{222}$ Application forms are also used for obtaining information. Many forms do not stop at questioning "have you ever been arrested" or "have you ever been convicted of any crime," but proceed to inquire "have you ever been taken into custody" and "have you appeared in any court." 223

Additionally, while statutes provide for control of court records, ${ }^{224}$ there have been virtually no attempts to control police records. ${ }^{225}$ In many jurisdictions the police maintain complete records of every contact with a juvenile and sometimes a duplicate is kept in a central index available to other police agencies. In almost all jurisdictions police have complete discretion as to the control of these records, and some frequently release information to those who request it-including law enforcement agencies, the armed forces, the F.B.I., social service agencies and private employers. ${ }^{226}$ Apparently, the only state which has attempted to deal

218 In re Contreras, 109 Cal. App. 2d 787, 789, 241 P.2d 631, 633 (1952).

218 See note 37 supra and accompanying text.

220 See D.C. Cope ANn. §16-2308(d) (Supp. V, 1966).

221 Antieau, Constitutional Rights in Juvenile Courts, 46 CORNel L.Q. 237, 389 (1961). See In re Schubert, 153 Cal. App. 2d 138, 141, 313 P.2d 968, 970 (1957), where the trial judge amended the petition so that the conduct charged was a misdemeanor instead of the felony: "This was so the boy could enlist in the armed services if he wanted to. Minors whose records show participation in felonies are not welcomed in the army or navy."

222 See Harvard Research Project 799-800.

223 Ibid.

224 See, e.g., Watkins v. United States, 343 F.2d 278 (D.C. Cir. 1964) ; D.C. Code Ann. \& 11-1586 (Supp. V, 1966).

225 See Harvard Research Project 784.

$226 I d$. at 785. 
with this problem is New York, where control of police records is lodged in the juvenile courts. ${ }^{227}$

If juvenile court litigation can result in punishment similar to punishment for crime, and stigma does attach to juvenile court litigation, what is left to support the contention that informal procedures are all that is necessary in the juvenile court? There is a real danger that informal procedures will distort the fact-finding process, and the fear that abusive treatment will be accorded the juvenile is not unfounded. The last argument remaining to the defenders of informality is that the hearing is part of the treatment, removing the juvenile from the traumatic experience of a criminal trial. Even if this were true, the obvious objection is that the system pays a high price for the return. But is it true? It is at least arguable that orderly, formal procedures will also have a therapeutic effect in demonstrating the dignity and fairness of the law to the juvenile offender and impressing him with the seriousness of his act. After the traumatic experiences of being arrested and going through the police process, how much more traumatic could any type of hearing be?

As long as juvenile courts are considered courts of law, they should so act, and it may not fairly be said that they are not criminal when they serve essentially the same function as criminal courts. Juvenile courts are not given supervisory power over all juveniles. Before a minor may be brought under the processes of that court the commission of an anti-social act, commonly referred to as a crime, must be proven. There is no excuse for requiring less than legally reliable proof of the act and fair procedures for presenting and evaluating such proof.

\section{ANother Proposal}

While there are grounds for criticizing the system as it now operates, the rehabilitative philosophy of the juvenile courts should not be abandoned. There is always hope that money will be spent to hire more and better personnel to staff the training schools and that repressive measures will be minimized. The purpose of this proposal is to suggest a system which retains the basic philosophy while establishing procedural protections consistent with current concepts of criminal justice. For purposes of clarity the model system will be described as if it presently existed.

Juvenile courts act as criminal courts. Once that piece of underbrush is cleared away, it is not so difficult to propose that the juvenile offender be given the same constitutional and procedural safeguards that are given to adult offenders. It might then be asked, if juveniles are to

227 All police records relating to the arrest and disposition of any person under this article shall be kept in files separate and apart from the arrests of adults and shall be withheld from public inspection, but such records shall be open to inspection upon good cause shown by the parent, guardian, next friend or attorney of that person upon written order of a judge of the family court . . .

N.Y. FAMILY CT. Acr § 784 . 
be tried under the same procedures as adults, why not merely abolish juvenile courts? The answer to this question must be held in abeyance until the dispositive function of the juvenile court is discussed.

Under the model system pre-trial procedures with certain modifications are the same as those used in cases concerning adults. The modifications are of the type needed to make adjustment to the special nature of the suspect involved. For example, the juvenile at all times prior to trial must be separated from other criminal suspects if he remains incarcerated during any part of that period. Also, a member of the probation department of the juvenile court must be notified upon arrest of a juvenile, and he must supervise all pre-trial detention and interrogation of the accused. The juvenile is afforded and informed of a right to counsel and, in the case of indigents, is offered appointment, following the same procedure used for adults in the jurisdiction. If the child is incapable of understanding the need for a lawyer, his parents are informed of the right. In cases where there is a conflict of interest between the parent and child, or where the judge finds that the parents are not capable of protecting the child's interests, he may appoint counsel to represent the child. The right to have bail set is extended.

The prosecutor assumes his normal function of presenting the state's case under regular rules of evidence. Since the prosecutor must try the case, he has joint responsibility with the probation officer to decide whether prosecution is appropriate. If indictment by grand jury is provided in the jurisdiction for adults, it is also provided for juveniles.

The use of confessions must be carefully scrutinized, and the constitutional standards enunciated by the United States Supreme Court and state courts concerning confessions and right to counsel must be applied. A pre-trial hearing is provided where the legality of a confession may be attacked, and confessions must be suppressed if shown to be improperly obtained. Similarly, constitutional interpretations and rulings in the jurisdiction concerning searches and seizures are fully applied.

The differentiation of the dispositive from the fact-finding function plays a major role in the new hearing procedure, since the intermingling of the two in one hearing has caused so many problems in the past. A bifurcated hearing, totally separating the two functions, is provided. During the fact-finding hearing, the right to trial by jury is granted, the strict rules of evidence apply, the juvenile is warned of his right not to incriminate himself, testimony is given only by sworn witnesses and counsel has the normal right of cross-examination. As previously mentioned, instead of the probation officer or the judge carrying the burden of presenting the state's case, the prosecutor assumes his usual role.

If a judge is sitting without jury, he is not permitted to read any material concerning the dispositive function, including social records and probation reports. Of course, under no circumstances is evidence concerning the dispositive function permitted in the fact-finding hearing, 
and the only situations where material relevant to that function might be presented are cases in which it is also relevant to the factual question before the court and admissible under the rules of evidence. The right to public trial is granted, but the child or his parent or guardian may request a private hearing after the court explains this option. After evidence is heard, the jury, or judge where jury trial is waived, announces a verdict or judgment under the ordinary burden of proof in criminal casesproof of guilt beyond a reasonable doubt. Jeopardy attaches at the same point it does in any criminal trial.

If the juvenile has been found to have committed the crime alleged, a dispositive hearing is held after a continuance during which the judge familiarizes himself with the entire record of the minor, what is known of his past and all social and psychological reports. Both the juvenile's counsel and the prosecutor may have access to these records as a matter of right, ${ }^{228}$ but otherwise confidentiality is generally preserved. Counsel for each side may submit material relevant to the disposition of the minor. The conduct of the dispositive hearing approximates present procedures utilized in most juvenile court hearings. The rules of evidence are greatly relaxed and all material relevant to the issue of what type of disposition is best for the juvenile is admissible. The judge is free to call witnesses he feels would aid in the determination, and he may be liberal in questioning from the bench. Cross-examination by counsel should be restrained and aimed solely at ascertaining what type of disposition would be best for the juvenile and society.

Confidentiality of all records is maintained, and only those having a direct interest in the litigation or the general welfare of the child are permitted to inspect them. This group would include parents, guardians, close relatives and officers of the court engaged in litigation concerning the child. Control of records, including files kept by the police, is the function solely of the juvenile court judge.

It is in the dispositive function that the expertise of a specialist judge is most useful; indeed, this special skill is the major reason for maintaining a separate juvenile court system. Sentencing in the juvenile court should be geared mainly toward the rehabilitation of the juvenile, with a secondary consideration being protection of the public. Punishment and deterrence should play a minor role. Thus, the seriousness of the offense is not nearly so important in sentencing in a juvenile court as in a normal criminal court. A judge who is trained or who trains himself in social sciences and deals with many juvenile offenders will almost of necessity develop a greater understanding of the problems involved than

228 This proposal adopts a somewhat expanded version of the rule announced in Watkins v. United States, 343 F.2d 278 (D.C. Cir. 1964). Under it, the juvenile offender is granted greater access to these records than Williams v. New York, 337 U.S. 241 (1949), seems to give adults. The most valid objection to wide-open disclosure is that it will deter persons from giving information to probation officers. If this in fact occurs, the proposal will require modification. 
a judge who deals with a broad range of cases. If we desire a specialist in the dispositive function, the same group of men ought to preside over the fact-finding hearings to save duplication. If it were otherwise, the specialist judge would be required to waste time and effort familiarizing himself with the events at the prior hearing, and would be deprived of observing the juvenile's demeanor at the hearing.

Under the proposed system the juvenile court judge is generally given great leeway in sentencing. Presently, a juvenile may be incarcerated only until age twenty-one, no matter how dangerous he may be and no matter what the chances for early rehabilitation. This limited incarceration is required because the minor is not given a "constitutional" trial. The proposed system permits longer incarceration because full constitutional rights have been granted.

In any case the juvenile may be sentenced to an institution up to the maximum period allowed under the criminal law for the crime committed and has the right to be released sooner when the juvenile authorities find he is sufficiently rehabilitated to take his place in society. As a check against arbitrary refusal to permit a rehabilitated offender to leave the institution, the juvenile court must periodically review cases of incarcerated juvenile offenders. This review must be made no less than every three to five years. In sentencing, the primary concern is the needs of the juvenile, but the judge must also consider the needs of society.

The suggested system totally obviates the need for waiver of jurisdiction if juvenile institutions are intelligently used and new ones established where necessary. By permitting longer periods of incarceration, the public will be protected against premature release of dangerous juvenile offenders. The difficulties of operating a system of juvenile institutions would be complicated, but by segregating roughly along age levels and by sorting out the more disturbed inmates from the others, most problems can be solved if sufficient financial resources are made available. 